\title{
Experimental modeling of the acute toxicity and cytogenotoxic fate of composite mixtures of chromate, copper and arsenate oxides associated with CCA preservative using Clarias gariepinus (Burchell 1822)
}

\author{
Olukunle S. Fagbenro', Chibuisi G. Alimba ${ }^{1,2 *}{ }^{1}$, Adekunle A. Bakare ${ }^{1}$ \\ ${ }^{1}$ Cell Biology and Genetics Unit, Department of Zoology, University of Ibadan, Ibadan, Nigeria; ${ }^{2}$ Leibniz Research Centre for Working Environment and \\ Human Factors (IfADo), Technical University of Dortmund, 44139 Dortmund, Germany
}

Concurrent occurrence of chromium ( $\mathrm{Cr}$ ), copper (Cu) and arsenic (As) from chromated copper arsenate (CCA) wood preservative in aquatic ecosystems demands that their joint-actions in eliciting toxic effects be assessed for adequate understanding of the health risk they may pose to biota. Clarias gariepinus was exposed to $\mathrm{As}_{2} \mathrm{O}_{3}, \mathrm{CrO}_{3}$ and $\mathrm{CuO}$ and their composite mixtures $(1: 1$ and $1: 1: 1)$ at various concentrations $(0-600 \mathrm{mg} / \mathrm{L})$ for $96-\mathrm{h}$ to determine the acute toxicity using OECD (1992) protocol. C. gariepinus was then exposed to sub-lethal concentrations corresponding to $6.25,12.5,25.0,50.0$ and 100\% of the $96-\mathrm{h}$ LC50 for 7 days to assess the cytogenotoxic effects using piscine micronucleus (MN) test. The 96-h LC50 showed that the metals/metalloid demonstrated differential interactions in a concentration dependent pattern. The 96-h LC50 showed that $\mathrm{Cr}$ was the most toxic while $\mathrm{Cu}$ and As: $\mathrm{Cu}$ were indeterminate $(\mathrm{Cr}>\mathrm{Cr}: \mathrm{Cu}>\mathrm{As}: \mathrm{Cr}>\mathrm{As}>\mathrm{As}: \mathrm{Cr}: \mathrm{Cu}>\mathrm{Cu}=\mathrm{As}: \mathrm{Cu}$ indeterminate). Isobologram and synergistic ratio (SR) models predicted antagonistic interaction between $\mathrm{Cu}: \mathrm{Cr}$ and $\mathrm{As}: \mathrm{Cr}$ and synergism between $\mathrm{As}: \mathrm{Cu}$ in the causation of morbidity and mortality of $C$. gariepinus. Interaction factor model predicted antagonism as common interactive mechanism among the metal/metalloid mixtures in the induction of MN and abnormal nuclear erythrocytes in C. gariepinus. Predicted interactions among the three metals/ metalloid were largely antagonism and synergism towards the induction of acute toxicity and cytogenotoxicity. The models employed herein may be useful in establishing environmental safe limits for mixtures of metals/metalloids against the induction of acute toxicity and DNA damage in lower aquatic vertebrates.

Keywords: Acute toxicity, antagonistic and synergistic interactions, Clarias gariepinus, joint-action toxicity models, metal mixtures, micronucleus test

\section{Introduction}

Accelerated urbanization and industrial developments are the major cause of unprecedented increase in worldwide chemical discharge into the environment. In most developing nations, generated chemicals are poorly managed by habitual illegal disposal on available spaces in the environment. Moreover, poor enforcement of laws and regulations prohibiting improper discharge of hazardous substances further encour-

Received: May 14, 2019 Accepted: September 19, 2019

Corresponding author: Chibuisi G. Alimba

Cell Biology and Genetics Unit, Department of Zoology, University of Ibadan, Ibadan, Nigeria

E-mail:cg.alimba@ui.edu.ng,chivoptera@yahoo.com

This article is available from: $h t t p: / / e a h t . o r g$ ages culprits. Most of the discharged chemical and physical agents cause great alterations in the biogeochemical circles of both aquatic and terrestrial ecosystems and in turn compromising human and ecosystem health [1]. Metals are the most commonly released chemicals into the environment via multiple direct and indirect sources [2]. A seemingly neglected direct source of toxic metal discharge is through chromated copper arsenate (CCA) wood treatment preservative [3-8]. The individual metals in CCA preservatives exist in varying compositions, hence they are classified into Types $A, B$ and $C$. The metal compositions range from 2100 - $2300 \mathrm{mg} / \mathrm{L}$ chromium trioxide $\left(\mathrm{CrO}_{3}\right), 1200$ - $1400 \mathrm{mg} / \mathrm{L}$ copper oxide $(\mathrm{CuO})$ and $1800-2200 \mathrm{mg} / \mathrm{L}$ arsenic trioxide $\left(\mathrm{As}_{2} \mathrm{O}_{3}\right)$. This is equivalent to $65.5 \%(\mathrm{Cr}), 18.1 \%(\mathrm{As})$ and $16.4 \%(\mathrm{Cu})$ in Type $\mathrm{A}, 35.3 \%(\mathrm{Cr})$, $19.6 \%(\mathrm{As})$ and $45.1 \%(\mathrm{Cu})$ in Type B, and $47.5 \%$ (Cr), $18.5 \%$ 
(As) and 34.0\% (Cu) in Type C [9]. Irrespective of the variations in the percentage compositions of individual elements in CCA, the leachability of the metals into the aquatic and terrestrial environments, is unaffected [5-7, 9-10]. Furthermore, studies have shown that individual metals in CCA readily leach from treated woods and timbers into aquatic and terrestrial environment at varying proportions and persist for about four decades $[4,7,10-15]$. Considering that CCA has a worldwide acceptance due to its effectiveness in protecting woods and timbers from fungal and insect attacks and its extensive usage for decades [9], may suggest threat to biota due to the high concentrations of the component metals/metalloid in the environment.

The individual metals/metalloid in CCA: chromium (Cr), copper $(\mathrm{Cu})$ and arsenic (As), are clastogens and or aneugens, teratogens, endocrine disruptors and potential tumor inducers [16-18]. Due to increasing health risk and environmental contamination ascribed to these metals, in 2003 all arsenic-based wood preservatives including CCA were restricted from used as preservative for decks and patios, picnic tables, playground equipment, walkways/boardwalks, landscaping timbers, and/ or fencing by the U.S. Environmental Protection Agency [19]. Despite its restriction, existing CCA-treated woods and structures will persistently leach $\mathrm{Cr}$, $\mathrm{Cu}$ and As into the environment for periods between 10 - 40 years $[7,11,15]$. This suggests that $\mathrm{Cr}, \mathrm{Cu}$ and As will continue to contaminate aquatic and terrestrial environments via wood wastes from construction, demolition and remodeling projects. Moreover, in many developing countries, CCA preservative is still in use either deliberately or illegally due to its effectiveness in protecting timbers and utility poles [20]. CCA coated timbers and poles are sometimes submerged in large water bodies to prolong their life shelves. This act leads to increase in leaching and direct release of $\mathrm{Cr}, \mathrm{Cu}$ and As into the water bodies [21]. In a recent study, Sogbamu et al. [22] asserted that the degradation of aquatic environment by illegal submerging of treated woods and timbers in Lagos Lagoon, is a common practice in Lagos State, Nigeria. It becomes imperative to routinely monitor these metals and assess their deleterious impacts in most environmental media so as to protect biota and human health. $\mathrm{Cr}, \mathrm{Cu}$ and As leaching from CCA persist in the aquatic sediments and water, soils and readily bio-accumulate in biota, particularly epibiotic organisms, that live on treated woods [23]. This poses a deleterious effect on animal diversity and subsequently human health [4]. For instance, American oysters (Crassostrea virginica) living in a CCA contaminated water body, bio-accumulated up to 600 $\mathrm{mg}$ of $\mathrm{Cu}$ which in turn significantly induced pathological lesions and clastogenicity in the Oysters' tissue $[24,25]$. Aquatic environment is particularly susceptible to the accumulation of $\mathrm{Cr}, \mathrm{Cu}$ and As during leachability from CCA treated wood, howbeit, there is dearth of information on the potential joint action toxicity of the metals in eliciting morbidity and mortality, growth retardation and induction of genetic instability in aquatic vertebrates. An increasing area of research focus in recent times, is the assessment of interactive effects among individual metals; which may lead to eliciting greater or lesser toxicity in biological systems via synergistic, antagonistic and/or additive interactive mechanisms [26-28]. The report herein is the first to utilize multi-model approach and cytogenetic biomarker to investigate the possible joint action toxicity of oxides of $\mathrm{Cr}, \mathrm{Cu}$ and As on aquatic vertebrates using Clarias gariepinus as a model organism.

\section{Materials and methods}

\section{Chemicals}

$\mathrm{As}_{2} \mathrm{O}_{3}$ (CAS No. 1327-53-3), $\mathrm{CrO}_{3}$ (CAS No. 1308-38-9), $\mathrm{CuO}$ (CAS No. 1317-38-0) and benzene in analytical grades were obtained from Sigma (St. Louis, MO).

\section{Animals}

Juvenile C. gariepinus (mean \pm SD body weight $11.00 \pm 1.00 \mathrm{~g}$ and length $9.40 \pm 1.50 \mathrm{~cm}$ ) obtained from the Fisheries Department, Oyo State Ministry of Agriculture and Natural Resources, (Ibadan, Nigeria) were used for this study. They were acclimatized for 14 days to laboratory conditions of $26.0 \pm$ $1.0^{\circ} \mathrm{C}$ and $12 \mathrm{~h}$ dark/light cycle prior to the experimental setup. They were stocked at a population density of 10 fish per 25 $\mathrm{L}$ transparent aquarium containing underground borehole water and fed twice daily with standard fish meal manufactured by Coppens ${ }^{\bullet}$.

\section{Study design}

Single action toxicity and joint action toxicity assessment of the metal solutions

Ten juvenile $C$. gariepinus per group, randomly selected into seven experimental groups per individual metal concentrations and their composite mixtures, were utilized for the $96-\mathrm{h}$ acute toxicity testing in accordance with standard regulations and guidelines for testing of chemicals [29]. Following range finding tests analysis for the metal oxides; 0 - $600 \mathrm{mg} / \mathrm{L}$ of the individual metals and their composite mixtures were selected for the acute toxicity study. The metal oxide solutions were prepared immediately before use and the $C$. gariepinus were not fed during the acute toxicity study (static bioassay). Mortality and clinical signs of toxicity were recorded by visual ex- 
Table 1. Metal/metalloid concentrations corresponding to $6.25,12.5,25,50$ and $100 \%$ of the $96-\mathrm{h} \mathrm{LC} \mathrm{C}_{50}$ for the individual and composite mixture of chromium (Cr), copper (Cu) and arsenic (As) utilized in the 7-day sub-lethal toxicity study

\begin{tabular}{lccccr}
\hline \multirow{2}{*}{ Metals } & \multicolumn{5}{c}{ Concentrations (mg/L) } \\
\cline { 2 - 6 } & $6.25 \%$ & $12.50 \%$ & $25 \%$ & $50 \%$ & $100 \%$ \\
\hline As & 13.31 & 26.63 & 53.25 & 106.51 & 213.01 \\
$\mathrm{Cr}$ & 3.86 & 7.71 & 15.42 & 30.84 & 61.68 \\
$\mathrm{Cu}$ & 6.25 & 12.5 & 25 & 50 & 100 \\
$\mathrm{As}: \mathrm{Cr}$ & $6.66+1.93$ & $13.32+3.86$ & $26.63+7.71$ & $53.26+15.42$ & $106.51+30.84$ \\
$\mathrm{As}: \mathrm{Cu}$ & $6.66+3.13$ & $3.86+6.25$ & $26.63+12.50$ & $53.26+25.00$ & $106.51+50.00$ \\
$\mathrm{Cr}: \mathrm{Cu}$ & $1.93+3.13$ & $8.88+2.57+4.17$ & $17.75+5.14+8.33$ & $35.50+10.28+16.66$ & $35.50+20.56+33.33$ \\
As:Cr:Cu & $4.44+1.29+2.08$ & &
\end{tabular}

Composite mixture referred to equal volumes of the individual metal solutions ( $\mathrm{mg} / \mathrm{L}$ ) (equal volume of binary=1:1 and tri-metal mixture=1:1:1).

amination at every $24 \mathrm{~h}$ during the 96-h exposure duration. Fish were considered dead when no movement was observed after gentle prodding with a glass rod. Environmental relevant safe concentrations (SC) for the individual metals/metalloid and their composite mixtures; As: $\mathrm{Cr}, \mathrm{As}: \mathrm{Cu}, \mathrm{Cr}: \mathrm{Cu}$ and As: $\mathrm{Cr}: \mathrm{Cu}$ (composite mixture as used herein referred to equal molar volumes of the metals corresponding to the selected percentages of the $\mathrm{LC}_{50}$ of individual metals in binary ratio $=1: 1$ and tri-metal ratio=1:1:1), at 96 -h exposure were derived by multiplying the $96-\mathrm{h} \mathrm{LC}_{50}$ by a factor of 0.1 in accordance with European Inland Fisheries Advisory Commission (EIFAC) [30].

\section{Sub-lethal toxicity and piscine micronucleus analysis}

Five concentrations corresponding to $6.25,12.5,25,50$ and $100 \%$ of the $96-\mathrm{h} \mathrm{LC}_{50}$ in $\mathrm{mg} / \mathrm{L}$ (metal solution/underground borehole water) for each of As, $\mathrm{Cr}, \mathrm{As}: \mathrm{Cr}, \mathrm{Cr}: \mathrm{Cu}$ and $\mathrm{As}: \mathrm{Cr}: \mathrm{Cu}$ were selected for the sub-lethal toxicity study (Table 1). Similarly, $6.25,12.5,25,50$ and $100 \%$ of $100 \mathrm{mg} / \mathrm{L}$ (metal solution/ underground borehole water) each for $\mathrm{Cu}$ and $\mathrm{As}: \mathrm{Cu}$ were selected in accordance with standard guidelines for testing of chemicals [29], since the $96-\mathrm{h} \mathrm{LC}_{50}$ of $\mathrm{Cu}$ and As:Cu, were indeterminate. The metal solutions were prepared immediately before use and each experimental set-up was renewed every 48-h to ensure constant exposure of test organisms to the metal oxide solutions and also avoid accumulation of metabolic wastes and remains of food particles. Similar treatment was given to fish exposed to borehole water as negative control and $0.10 \mathrm{~mL} / \mathrm{L}$ of benzene, a hematopoietic genotoxic inducer [31], as positive control. Fish in the control and exposed groups were weighed (initial weight gain) before the commencement of exposure using Acculab ${ }^{\bullet}$ USA, Model-vic-303 electronic analytical weighing balance. At 7-day post exposure, fish from the control and exposed groups were weighed (terminal weight gain) and peripheral blood collected through the caudal vein for slide preparation. Thin blood smears were prepared on three pre-clean and grease free microscope slides per fish [32]. The prepared slides were allowed to air dry for 24 -h, fixed in absolute $(98 \%, v / v)$ cold methanol $\left(4^{\circ} \mathrm{C}\right)$ for 30 min and counter stained with 5\% Giemsa and May-Grunwald stains for $20 \mathrm{~min}$. 2000 cells per slide were analyzed for MN and nuclear abnormalities (NAs) in accordance with standard protocols [33,34].

\section{Statistical analysis}

\section{Analysis of the concentration - response data}

Data obtained from the 96-h mortality were analyzed using probit method with SPSS $16.0^{\circ}$ computer program. The analyzed acute toxicity indices were presented as $\mathrm{LC}_{5}$ (sub-lethal concentration that induced $5 \%$ mortality of test model), $\mathrm{LC}_{50}$ (median lethal concentration that induced 50\% mortality of test model) and LC $_{95}$ (lethal concentration that induced $95 \%$ mortality of test model). Toxicity factor (TF) for 24 hourly relative potency measurements for the metals were determined in accordance with standard procedure [28]:

$$
\mathrm{TF}=\frac{96-\mathrm{h} \mathrm{LC}_{50} \text { of a chemical }}{96-\mathrm{h} \mathrm{LC} \mathrm{C}_{50} \text { of equivalent chemical }}
$$

The interactive effects of individual metals in the composite mixtures were defined by the following models:

Synergistic ratio (SR) model: This model predicts the metal that greatly contributed to the observed toxicity in metal mixture [35]. It is determined as follows:

$$
\mathrm{SR}=\frac{96-\mathrm{h} \mathrm{LC} \text { - of a metal acting alone }}{96-\mathrm{h} \mathrm{LC} \mathrm{L}_{50} \text { of the mixtures of metals }}
$$

For this interaction model: when $\mathrm{SR}=1$ it is additive; $\mathrm{SR}<1$ it is antagonistic; and $\mathrm{SR}>1$ it is synergistic interactions.

Concentration-addition model: This model assumes that the addition of similarly acting toxicants are mixed in varying proportions, they will add up to give the observed response [36]. In evaluating the joint-action, a predicted $\mathrm{LC}_{50}$ is derived by summing up the $\mathrm{LC}_{50}$ values of the individual toxicants ac- 
cording to the proportion of their contribution in the mixture. The predicted $\mathrm{LC}_{50}$ is then compared with the observed $\mathrm{LC}_{50}$ of the mixture. The outcome classifies the pattern of interaction among the component metals of the mixture. The relationship between the derived $\mathrm{LC}_{50}$ and predicted $\mathrm{LC}_{50}(\mathrm{RTU})$ is estimated as:

$$
\begin{aligned}
& \text { Relative toxicity } \\
& \text { unit }(\mathrm{RTU})=\frac{\text { Predicted } \mathrm{LC}_{50} \text { value }}{\text { Experimentally observed } \mathrm{LC}_{50} \text { value }}
\end{aligned}
$$

For this interaction model: RTU=1 explains addictive; RTU < 1 explains antagonistic and RTU $>1$ explains synergistic interactions.

Isobologram describes the graphical presentation of jointaction toxicity of individual metals in a binary mixture [37]. Isobologram was used to show the pattern of interactions between individual metals in the binary mixture of the metal solutions that produced the biological response during the 96-h acute toxicity $\left(96-\mathrm{h} \mathrm{LC}_{50}\right)$.

The percentage weight gain of fish was determined using the formula:

Percentage (\%)

$$
\text { weight gain }=\frac{\text { Terminal weight }- \text { Initial weight }}{\text { Initial weight }} \times 100
$$

\section{Micronucleus test analysis}

The data obtained for $\mathrm{MN}$ and NAs are presented as mean \pm standard error (SE). One-way analysis of variance (ANOVA) was used to determine the difference $(\mathrm{p}=0.05)$ among the various exposed and control groups. Significant difference between each treatment group and the negative control was determined using Dunnett multiple post-hoc test (DMPT) at $\mathrm{p}=0.05$. The interaction factor (IF) between the binary and among the tri-metal constituents that led to the induction of $\mathrm{MN}$ and NAs, were determined in accordance with Katsifis et al. [38] and Danesi et al. [39] formula with slight modification:

$$
\mathrm{IF}=(\mathrm{CCA}-\mathrm{T})-[(\mathrm{C}-\mathrm{T})+(\mathrm{C}-\mathrm{T})+(\mathrm{A}-\mathrm{T})]
$$

where CCA is the statistical mean of the assessed biomarker induced by the mixtures of CCA solutions; C, C and A are means of biomarkers induced by individual metals present in the binary and tri-metal mixtures; while $\mathrm{T}$ is the mean of the negative control (borehole water).

Also, standard error (SEIF) for IF calculation is derived from: $\mathrm{SE}_{\mathrm{IF}}=\sqrt{\left(\left(\mathrm{SE}_{\mathrm{CCA}}\right)^{2}+\left(\mathrm{SE}_{\mathrm{C}}\right)^{2}+\left(\mathrm{SE}_{\mathrm{C}}\right)^{2}+\left(\mathrm{SE}_{\mathrm{A}}\right)^{2}+\left(\mathrm{SE}_{\mathrm{T}}\right)^{2}\right)}$

where $\mathrm{SE}_{\mathrm{IF}}$ is the standard error of IF; $\mathrm{SE}_{\mathrm{CCA}}, \mathrm{SE}_{\mathrm{C}}, \mathrm{SE}_{\mathrm{C}}, \mathrm{SE}_{\mathrm{A}}$, and $\mathrm{SE}_{\mathrm{T}}$ are standard error for $\mathrm{CCA}, \mathrm{C}, \mathrm{C}, \mathrm{A}$ and $\mathrm{T}$ respectively. When IF value is negative, it is antagonism; when it is positive, it is synergism; and when it is zero, it is additivity.

\section{Results}

Joint-action toxicity of binary and tri-metal mixtures of chromium, copper and arsenic on Clarias gariepinus

The individual metal solution and their mixtures induced dif-

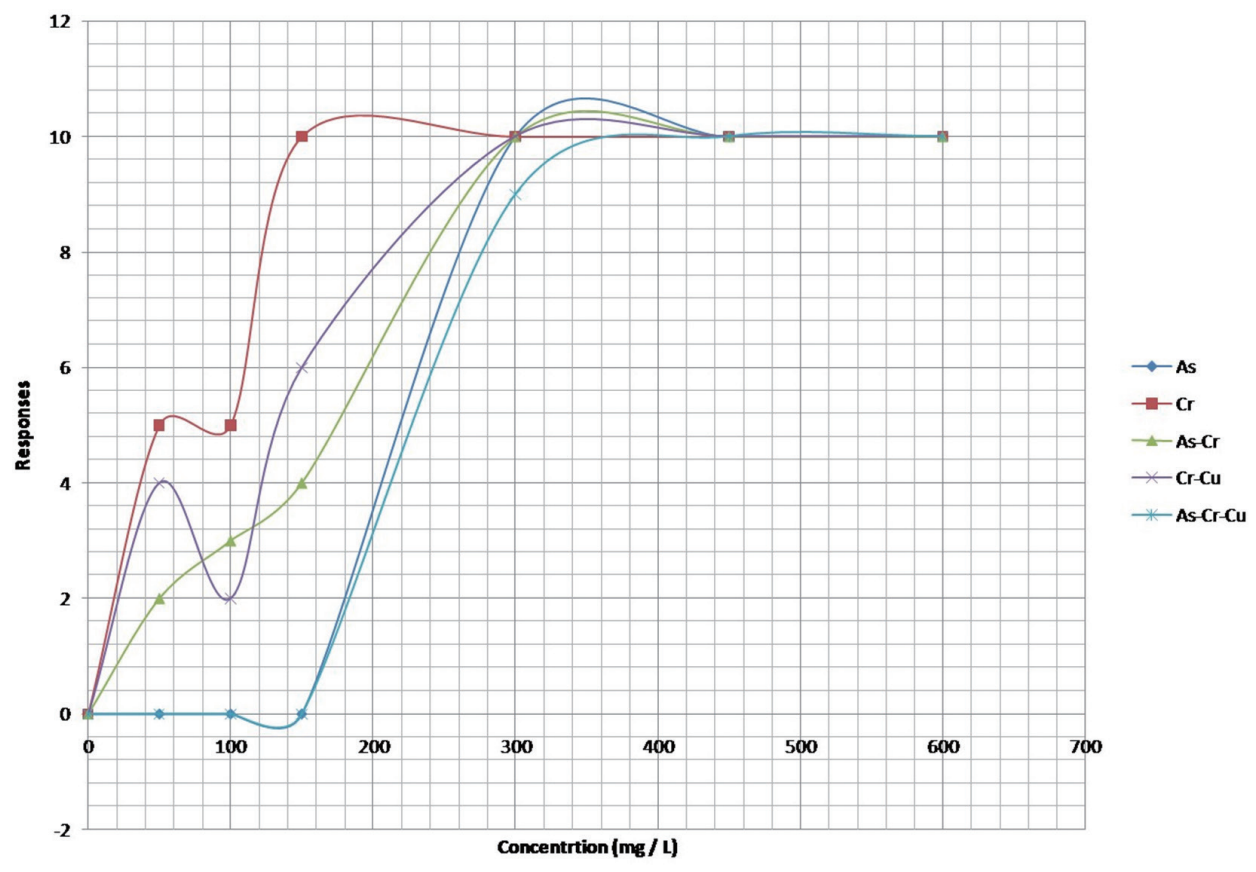

Figure 1. Percentage mortality of juvenile Clarias gariepinus exposed to varying concentrations of individual and composite mixtures of chromium (Cr), copper(Cu) and arsenic (As) oxides for $96 \mathrm{~h}$. Number of fish per concentrations $=10$ fish. 
ferent rate of mortality on juvenile stage of $C$. gariepinus. $\mathrm{Cu}$ alone and As:Cu mixture did not induce any mortality even at the highest selected concentrations (600 mg/L). Mortality was only recorded at higher concentrations (300 - $600 \mathrm{mg} / \mathrm{L}$ ) for As and As:Cr:Cu mixture, while mortality increased with concentrations for $\mathrm{Cr}$, As: Cr and $\mathrm{Cr}: \mathrm{Cu} .100 \%$ mortality of the test model was recorded at $150 \mathrm{mg} / \mathrm{L} \mathrm{Cr}, 300 \mathrm{mg} / \mathrm{L} \mathrm{As}$, As:Cr and $\mathrm{Cr}: \mathrm{Cu}$ and $450 \mathrm{mg} / \mathrm{L} \mathrm{As:Cr:Cu}$ (Figure 1). The 24-h LC $\mathrm{LCC}_{50}$ and $\mathrm{LC}_{95}$ revealed that the concentration dependent increase mortality induced by $\mathrm{Cr}>\mathrm{Cr}$ :Cu $>\mathrm{As}: \mathrm{Cr}>\mathrm{As}>\mathrm{As}: \mathrm{Cr}: \mathrm{Cu}$ in that order, was also exposure duration related. This shows that $\mathrm{Cr}$ (96$\mathrm{h} \mathrm{LC}{ }_{50}=61.68 \mathrm{mg} / \mathrm{L}$ ) was the most toxic metal (Table 2) and $\mathrm{Cu}$ and As:Cu the least toxic since there was no observed mortality at all tested concentrations ( $96-\mathrm{h} \mathrm{LC}_{50}=$ indeterminate). The environmental SC for $\mathrm{Cr}, \mathrm{As}, \mathrm{As}: \mathrm{Cr}, \mathrm{Cr}: \mathrm{Cu}$ and $\mathrm{As}: \mathrm{Cr}-\mathrm{Cu}$ with respect to the juvenile sized $C$. gariepinus used herein are 6.17, $21.30,12.28,10.04$ and $25.46 \mathrm{mg} / \mathrm{L}$ respectively. Also, the de- rived TF showed that Cr was 4.13 fold more toxic than $\mathrm{As}: \mathrm{Cr}: \mathrm{Cu}$ $(\mathrm{TF}=1.00)$ (Table 2).

Possible mode of interactions among chromium, copper and arsenic solutions predicted from the mortality data obtained from exposed juvenille Clarias gariepinus

The experimentally determined $96-\mathrm{h} \mathrm{LC}_{50}$ values for $\mathrm{Cr}, \mathrm{Cu}$ and As and their composite mixtures, suggest that some forms of interactions existed among the binary and tri-metal mixtures that led to the mortality of $C$. gariepinus. For instance, the composite mixture of $\mathrm{Cr}$ :Cu was less toxic to C. gariepinus compared to $\mathrm{Cr}$ (Table 2), but more toxic to C. gariepinus compared to $\mathrm{Cu}\left(96-\mathrm{h} \mathrm{LC}_{50}=\right.$ indeterminate). Similarly, the composite mixture of Cr:As was less toxic to the fish compared to individual $\mathrm{Cr}$ and As (Table 2). Meanwhile, the composite mixture of As:Cu did not induce mortality even at $600 \mathrm{mg} / \mathrm{L}$ similar response to $\mathrm{Cu}$, but As was more toxic than $\mathrm{As}$ : $\mathrm{Cu}$ mix-

Table 2. 96-h acute toxicity of individual and composite mixtures of chromium (Cr), copper (Cu) and arsenic (As) using juvenile stage of Clarias gariepinus

\begin{tabular}{|c|c|c|c|c|c|c|c|}
\hline Exposure Time (h) & $\mathrm{LC}_{5}(95 \% \mathrm{Cl})$ & LC50 $(95 \%$ Cl) & LC95 $(95 \%$ Cl) & Slope \pm SE & Probit line equation & TF & SC \\
\hline \multicolumn{8}{|c|}{ As } \\
\hline 24 & $280.32(151.59-341.00)$ & $441.02(335.72-475.29)$ & 602.65 (511.57-962.72) & $9.90 \pm 2.86$ & $Y=-25.87+9.90 X$ & & \\
\hline 96 & $185.27(70.29-228.41)$ & 213.01 (127.06-306.02) & 244.90 (367.82-726.38) & $27.15 \pm 76.34$ & $Y=-63.21+27.15 X$ & 1.19 & 21.3 \\
\hline \multicolumn{8}{|c|}{$\mathrm{Cr}$} \\
\hline 24 & 185.27 (70.29-228.41) & $213.01(127.06-306.02)$ & $244.90(367.82-726.38)$ & $27.15 \pm 76.34$ & $Y=-63.21+27.15 X$ & & \\
\hline 96 & $19.40(1.45-36.97)$ & $61.68(27.50-86.75)$ & $196.10(129.56-819.10)$ & $3.28 \pm 1.04$ & $Y=-5.86+3.28 X$ & 4.13 & 6.17 \\
\hline \multicolumn{8}{|c|}{$\mathrm{As}-\mathrm{Cr}$} \\
\hline 24 & 138.38 (65.59-190.48) & $283.70(213.71-352.55)$ & 581.64 (448.78-1012.45) & $5.28 \pm 1.21$ & $Y=-12.94+5.28 X$ & & \\
\hline 96 & 42.15 (16.57-63.98) & $122.82(88.47-165.68)$ & 357.88 (242.87-834.52) & $3.54 \pm 0.78$ & $Y=-7.40+3.54 X$ & 2.07 & 12.28 \\
\hline \multicolumn{8}{|c|}{$\mathrm{Cr}-\mathrm{Cu}$} \\
\hline 24 & 126.17 (58.90-176.62) & 288.86 (219.51-367.68) & 661.31 (488.17-1282.91) & $4.57 \pm 1.02$ & $Y=-11.25+4.57 X$ & & \\
\hline 96 & $27.83(0.00-66.45)$ & $100.41(1.37-277.56)$ & 362.27 (173.41-535.10) & $2.95 \pm 0.60$ & $Y=-11.25+4.57 X$ & 2.54 & 10.04 \\
\hline \multicolumn{8}{|c|}{ As-Cr-Cu } \\
\hline 24 & 259.65 (137.50-319.79) & 395.50 (322.01-480.61) & $602.42(504.68-993.30)$ & $9.00 \pm 2.55$ & $Y=-23.38+9.00 X$ & & \\
\hline 96 & 205.97 (84.66-197.48) & $254.56(217.35-382.44)$ & $314.61(254.01-518.33)$ & $17.88 \pm 53.34$ & $Y=-43.02+17.88 X$ & 1.00 & 25.46 \\
\hline
\end{tabular}

LCX: Lethal concentration that caused $\mathrm{x} \%$ mortality of exposed C. gariepinus at $95 \% \mathrm{Cl}$ (lower and upper limits); TF = Toxicity factor derived from $96-\mathrm{h} \mathrm{LC}$ 50; $\mathrm{Cl}=95 \%$ confidence interval; SE = Standard Error; SC = Safe concentration predicted for the juvenile size C. gariepinus in its environment.

Table 3. Synergistic ratio (SR) and concentration-addition unit (RTU) models derived from using the experimentally 96-h LC 50 obtained for both binary mixtures and individual chromium (Cr), copper (Cu) and arsenic (As) oxides

\begin{tabular}{|c|c|c|c|c|c|}
\hline Metal mixtures & $\begin{array}{l}\text { Experimentally observed } \\
\text { 96-h LC } 50 \text { (mg/L) }\end{array}$ & SR1 & SR2 & SR1/SR2 & Action \\
\hline Cr:As & 122.82 & 0.502 & 1.734 & 0.290 & Antagonism \\
\hline $\mathrm{As}: \mathrm{Cu}$ & 100.00 & 2.130 & 1.000 & 2.130 & Synergism \\
\hline \multirow[t]{2}{*}{$\mathrm{Cu}: \mathrm{Cr}$} & 100.41 & 0.614 & 0.996 & 0.616 & Antagonism \\
\hline & Predicted 96-h LC $\mathrm{C}_{50}(\mathrm{mg} / \mathrm{L})$ & $\begin{array}{l}\text { Experimentally observed } \\
96-\mathrm{h} \mathrm{LC} \mathrm{C}_{50}(\mathrm{mg} / \mathrm{L})\end{array}$ & RTU & Response & \\
\hline As:Cr & 274.69 & 122.82 & 2.24 & Synergism & \\
\hline $\mathrm{Cr}: \mathrm{Cu}$ & 161.68 & 100.41 & 1.61 & Synergism & \\
\hline $\mathrm{As}: \mathrm{Cu}$ & 313.01 & 100.00 & 3.13 & Synergism & \\
\hline As:Cr:Cu & 374.69 & 254.56 & 1.47 & Synergism & \\
\hline
\end{tabular}

$100 \mathrm{mg} / \mathrm{L}$ was used in cases where 96-h LC 50 value is indeterminable (in this case; As:Cu) in accordance with OECD, (1992). When SR1/SR2 = 1 indicates additivity; SR1/SR2 $>1$ indicates synergism; SR1/SR2 < 1 indicates antagonism. The predicted $96-h L_{50}=$ Sum total of single action 96-h LC 50 values; RTU = 1 indicates additivity; RTU $>1$ indicates synergism; RTU $<1$ indicates antagonism. 
ture to the fish. The tri-metal mixture; $\mathrm{Cr}: \mathrm{As}: \mathrm{Cu}$ (1:1:1) was less toxic to the fish compared to mortality responses from $\mathrm{Cr}$ and As, but more toxic than $\mathrm{Cu}$.

The joint-action toxicity models present different predictions to explain the possible interactions involved. SR model predicted antagonism between As and Cr (0.290), synergism between $\mathrm{As}$ and $\mathrm{Cu}$ (2.130) and synergism between $\mathrm{Cr}$ and $\mathrm{Cu}$ (0.616) (Table 3). Similarly, the $\mathrm{LC}_{50}$ data determined for both individual and composite binary mixtures were fitted into Isobolograms and compared with the theoretical model derived by Tallarida [37] (Figure 2). The analysis predicted antagonism as possible mechanisms of interaction between $\mathrm{As}$ and $\mathrm{Cr}$, and between $\mathrm{Cr}$ and $\mathrm{Cu}$ but synergism between $\mathrm{As}$ and $\mathrm{Cu}$ (Figure 2). While concentration-addition model predicted synergistic mode of interaction for all the composite binary mixtures; As: $\mathrm{Cr}$ (2.24), $\mathrm{Cu}: \mathrm{Cr}$ (1.61), As: $\mathrm{Cu}$ (3.13) and tri-metal mixtures; As:Cr:Cu (1.47) (Table 3).

\section{Clinical signs of toxicity and mortality induced by} individual and composite mixtures in Juvenile Clarias gariepinus

During the 96-h acute toxicity testing, the exposed fish showed various signs of toxicity in response to individual and composite mixtures of $\mathrm{Cr}, \mathrm{Cu}$ and As exposure. Fish exhibited erratic and fast movements when newly introduced into metal solutions, with an attempt to jumping out of the aquarium. With exposure time they began to move sluggishly while becoming weak (signs of reduced activities) and eventually died. However, it is interesting to note that such erratic movement though common with As, but fish mortality occurred only at higher concentrations, as fish became adjusted and survived at lower concentrations of As. These signs were mostly observed in the following metal solutions and in the order: As $>$ Cr $>$ As$\mathrm{Cr}>\mathrm{Cr}-\mathrm{Cu}>\mathrm{Cr}-\mathrm{Cu}-\mathrm{As}$. Fish exposed to $\mathrm{Cu}$ and mixture of $\mathrm{As}-\mathrm{Cu}$ did not display prominently such behavioral signs and they all survived even after the $96-\mathrm{h}$ acute toxicity period at all tested concentrations. As, $\mathrm{Cr}$ and As:Cr induced some gross pathology. For instance, fish exposed to composite mixture of As:Cr presented ulceration of the genital opening. There were inflammation of the blood vessels at the ventral surface of fish exposed to As, skin lesion at the ventral view of a fish exposed to Cr solution, and ulceration of the genital opening of fish exposed to composite mixtures of As:Cr (Figure 3). During exposure to the selected sub-lethal concentrations (Table 1) of indi-
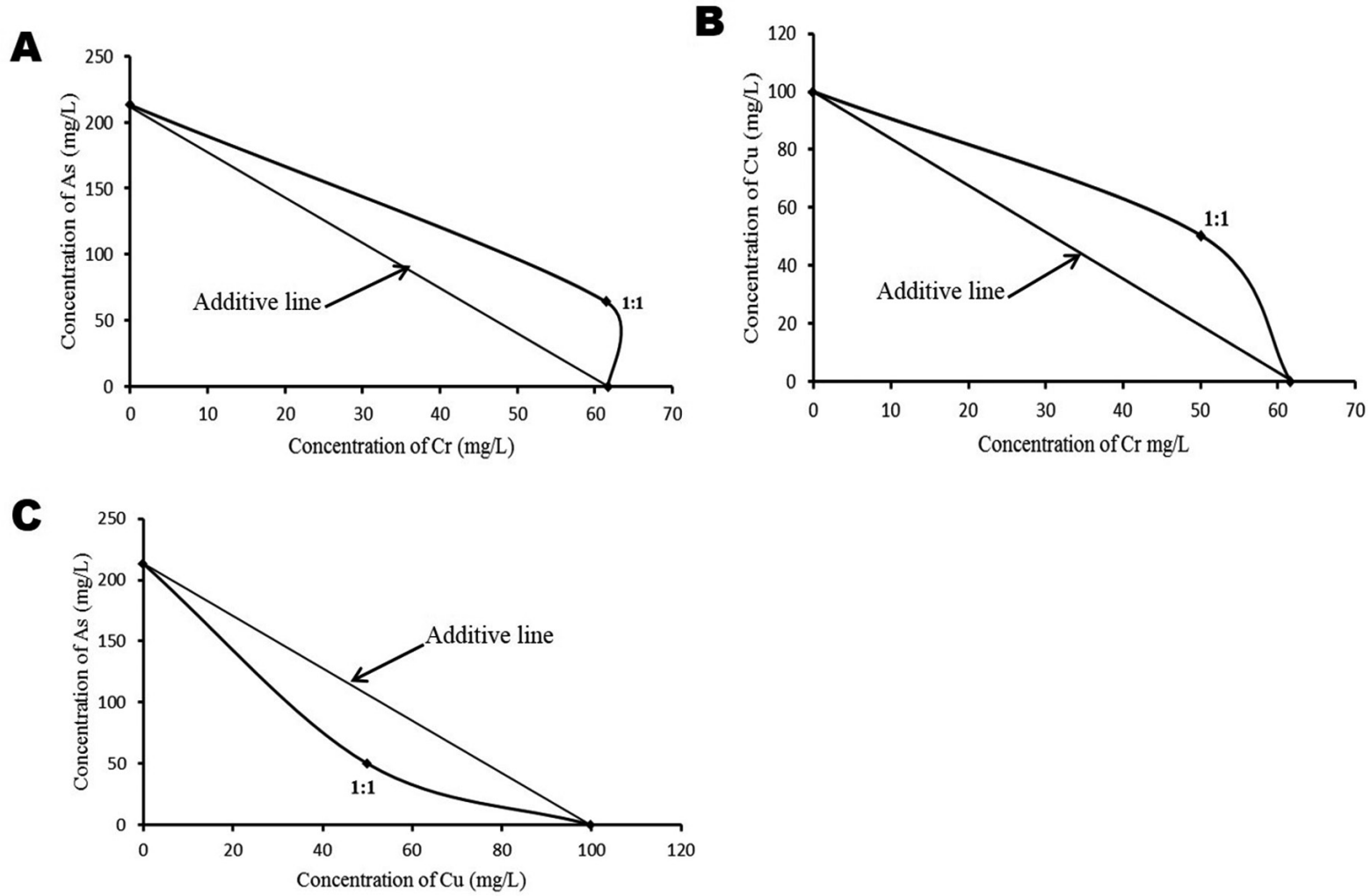

Figure 2. Isobologram presentations of the joint-action toxicity of the individual metals/metalloid using the experimentally obtained $96 \mathrm{~h} \mathrm{LC} 5_{50}$ value for each metal/metalloid; Isobole (A) for arsenic(As) : Chromium (Cr) interaction depicts antagonism, Isobole (B) for copper (Cu): Cr interaction depicts antagonism while Isobole (C) for As:Cu interaction depicts synergism. 
vidual and mixtures of the metals/metalloid for 7 days, all fish in the treatment groups; $\mathrm{Cr}, \mathrm{Cr}: \mathrm{Cu}, \mathrm{As}: \mathrm{Cr}$ and As:Cr:Cu presented significant $(p<0.05)$ body weight loss compared to the negative control. While fish exposed to As, $\mathrm{Cu}$ and As: $\mathrm{Cu}$ metal solutions showed significant $(\mathrm{p}<0.05)$ increase in body weight gain compared to negative control (Figure 4 ).
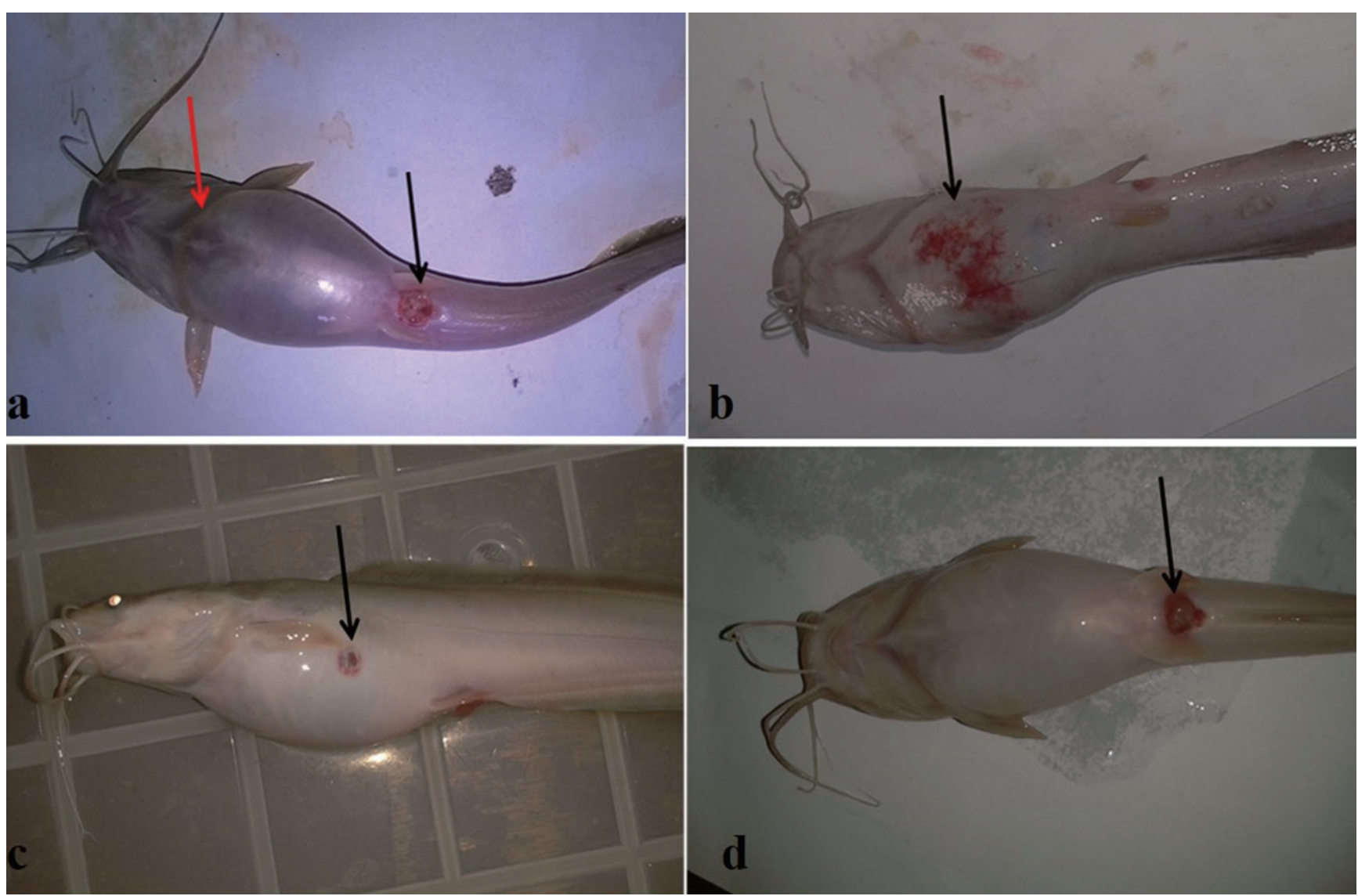

Figure 3. Clinical signs of toxicity observed in Clarias gariepinus exposed to varying concentrations of chromium (Cr), copper (Cu) and arsenic (As) oxides and their composite mixture for $96 \mathrm{~h}$. (a) Swelling of the skin (red arrow) and ulceration of the genital opening (black arrow) in fish exposed to composite mixture of As:Cr solutions. (b) Inflammation of the vascular blood vessels at the ventral view (black arrow) of fish exposed to As solution. (c) Skin lesion at the ventral view (black arrow) of fish exposed to Cr solution. (d) Ulceration of the genital opening (black arrow) of fish exposed to composite mixtures of AsCr solution.

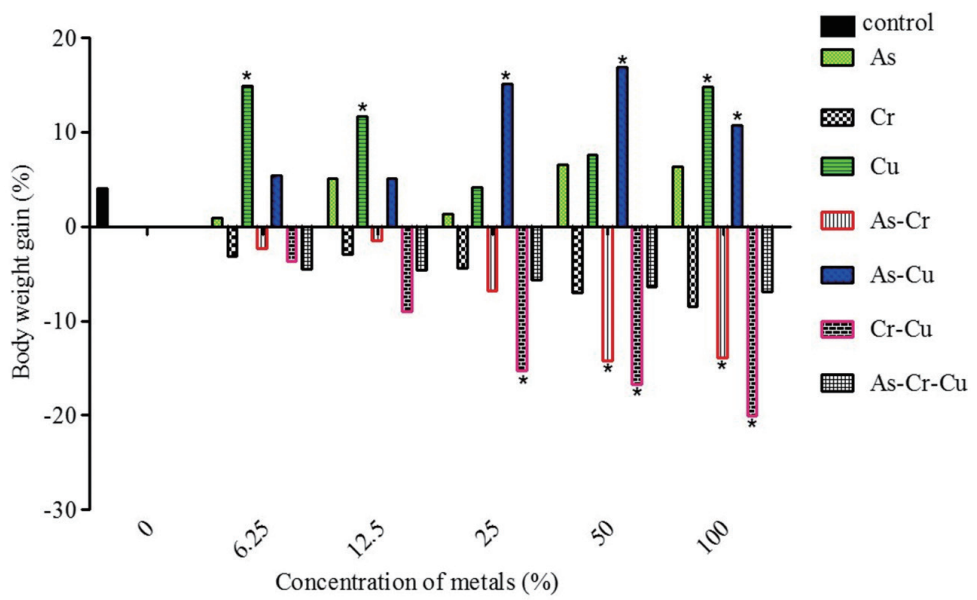

Figure 4. Percentage body weight gain by Clarias gariepinus in response to sub-lethal concentrations of chromium (Cr), copper (Cu), arsenic (As) oxides and their mixture during treatment for 7 days. Each bar represent mean $(n)=10$ fish. ${ }^{*} p<0.05$. 

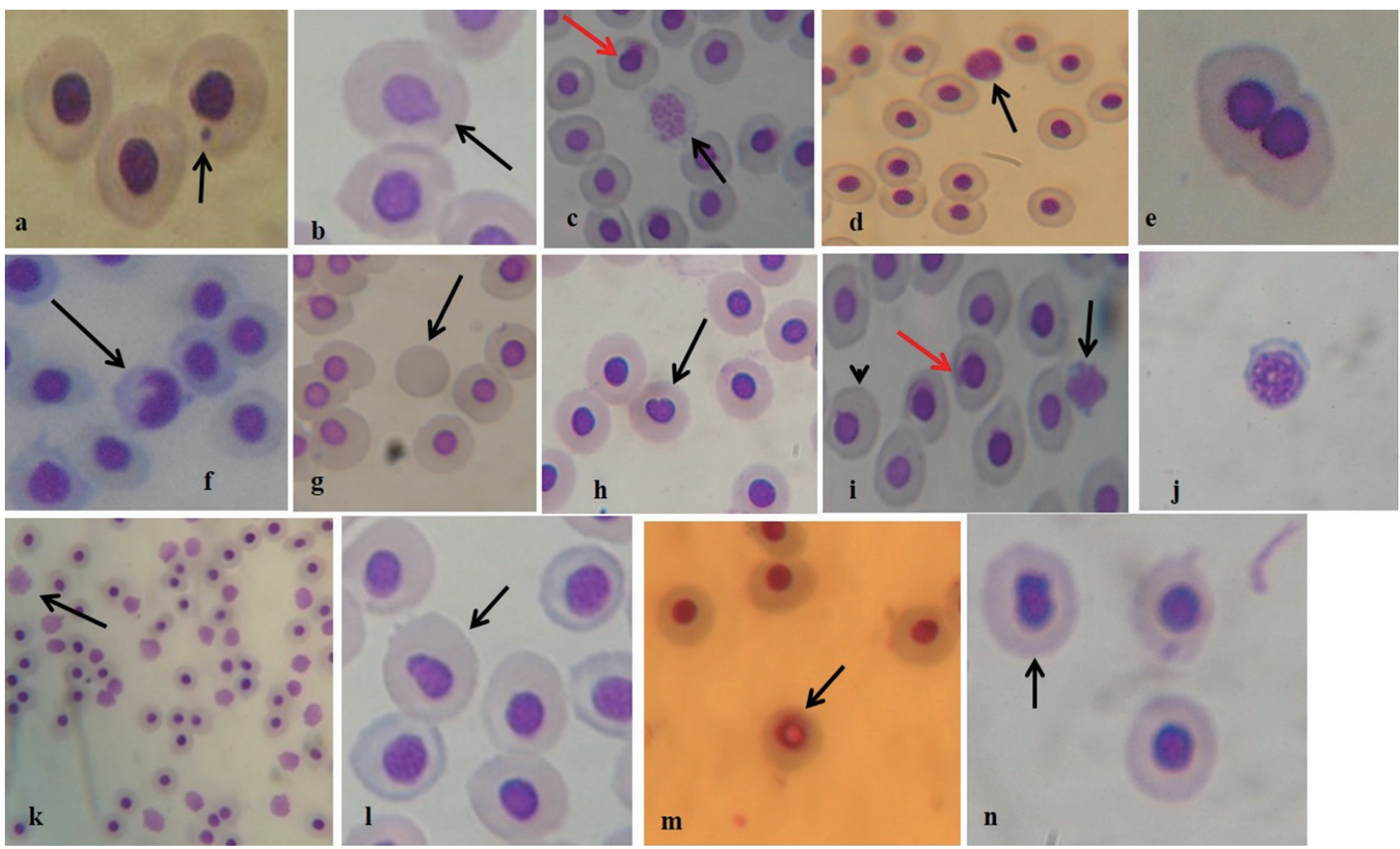

Figure 5. Micronucleated (MN) and abnormal nuclei erythrocyte formed in fish exposed to different concentrations of individual and mixture of chromium (Cr), copper (Cu) and arsenic (As) oxides for 7 days. (a) MN erythrocyte; (b) erythrocyte with nuclear bud; (c) nuclear fragmented erythrocyte (black arrow) and eroded nucleus (red arrow); (d) necrotic erythrocyte (e) binucleated erythrocyte; (f) erythrocyte with nuclear notch (g) enucleated erythrocyte; (h) erythrocyte with bleb nucleus; (i) early stage necrotic erythrocyte (black arrow), erythrocyte with nuclear bud (arrow head), eroding nucleus (red arrow); (j) early stage of nuclear fragmentation, (k) numerous necrotic erythrocytes (arrow), (l) erythrocyte with beans shaped nucleus (arrow), (m) erythrocyte with vacuolated nucleus, (n) erythrocyte with bilobe nucleus.

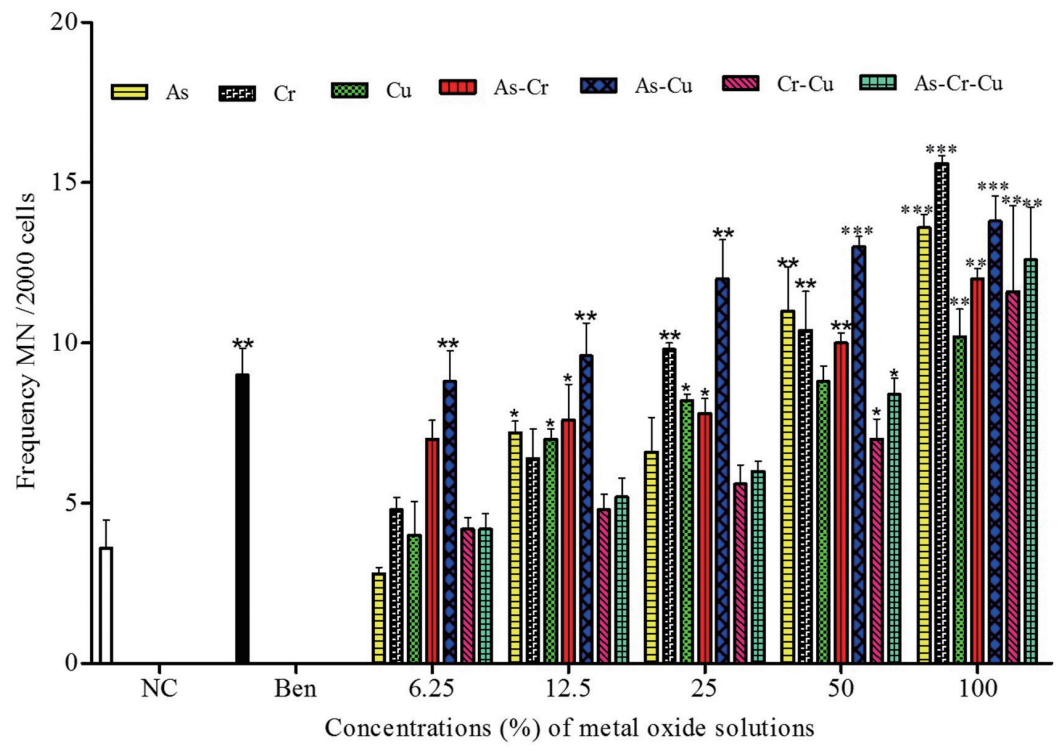

Figure 6. Frequency of micronucleated erythrocytes in peripheral blood of C. gariepinus exposed to arsenic (As), copper (Cr), copper (Cu), As:Cr, As:Cr, $\mathrm{Cr}: \mathrm{Cu}$ and As:Cr:Cu. ${ }^{\star} \mathrm{p}<0.05 ;{ }^{* \star} \mathrm{p}<0.01 ;{ }^{* \star \star} \mathrm{p}<0.001$ are significantly different from the negative control using Dunnett's multiple post hoc comparison test. Ben-Benzene $(0.10 \mathrm{~mL} / \mathrm{L}), \mathrm{NC}$ - Negative control. 
Chromium, copper and arsenic and their composite mixtures increased frequencies of micronucleated erythrocyte and erythrocyte with nuclear abnormalities in peripheral blood of Clarias gariepinus

There was significant increase in the frequency of MN (Figure 5a) in peripheral erythrocytes of $C$. gariepinus treated with the various sub-lethal concentrations of individual and mixtures of metals/metalloid compared to the negative control. $\mathrm{MN}$ induction showed concentration dependent and positive correlation with metals; $\mathrm{Cr}(\mathrm{p}<0.0001, \mathrm{r}=0.859, \mathrm{~F}=28.46)$, As: $\mathrm{Cu}(\mathrm{p}<0.0001, \mathrm{r}=0.757, \mathrm{~F}=14.53)$, As ( $\mathrm{p}<0.0001, \mathrm{r}=0.821$, $\mathrm{F}=21.53)$, As:Cr:Cu ( $\mathrm{p}<0.0001, \mathrm{r}=0.750, \mathrm{~F}=14.06) ;$ As: $\mathrm{Cr}(\mathrm{p}<$ 0.0001, r=0.745, F=13.57), $\mathrm{Cr}: \mathrm{Cu}(\mathrm{p}=0.0004, \mathrm{r}=0.558, \mathrm{~F}=5.90)$ and $\mathrm{Cu}(\mathrm{p}<0.0001, \mathrm{r}=0.725, \mathrm{~F}=12.37)$ (Figure 6). At the $100 \%$ concentration which corresponds to $96-\mathrm{h} \mathrm{LC}_{50}$ values for the individual and mixtures of metals/metalloid, fold increase in frequencies of $\mathrm{MN}$ was in the order: $\mathrm{Cr}$ (4.33 fold)>As: $\mathrm{Cu}(3.83$ fold $)>$ As $(3.78$ fold $)>$ As: $\mathrm{Cr}: \mathrm{Cu}(3.50$ fold $)>\mathrm{As}: \mathrm{Cr}(3.33$

Table 4. Nuclear abnormalities (NAs) and total nuclear abnormalities (TNAs) in peripheral erythrocytes of Clarias gariepinus exposed to individual and composite mixtures of chromium (III) oxide $\left(\mathrm{CrO}_{3}\right)$, copper oxide (CuO) and arsenate (III) oxide $\left(\mathrm{As}_{2} \mathrm{O}_{3}\right)$

\begin{tabular}{|c|c|c|c|c|c|c|c|}
\hline \multirow{2}{*}{ NAs } & \multirow{2}{*}{ Tap water } & \multirow{2}{*}{ Benzene } & \multicolumn{5}{|c|}{$\%$ Concentrations (mg/L). } \\
\hline & & & 6.25 & 12.5 & 25 & 50 & 100 \\
\hline \multicolumn{8}{|l|}{$\mathrm{As}_{2} \mathrm{O}_{3}$} \\
\hline BN & $0.20 \pm 0.20$ & $0.80 \pm 0.37^{\mathrm{a}}$ & $0.40 \pm 0.24$ & $0.20 \pm 0.20$ & $0.40 \pm 0.24$ & $1.40 \pm 0.24^{\mathrm{a}}$ & $1.00 \pm 0.32$ \\
\hline BUD & $0.00 \pm 0.00$ & $1.40 \pm 0.51$ & $0.80 \pm 0.20$ & $1.80 \pm 0.20^{\mathrm{a}}$ & $1.20 \pm 0.58$ & $2.20 \pm 0.37^{c}$ & $3.60 \pm 0.68^{c}$ \\
\hline FRA & $0.40 \pm 0.24$ & $0.80 \pm 0.37$ & $3.40 \pm 0.24^{c}$ & $6.20 \pm 0.37^{\circ}$ & $8.80 \pm 0.37^{\circ}$ & $10.00 \pm 0.89^{c}$ & $10.80 \pm 0.73^{c}$ \\
\hline NEC & $1.00 \pm 0.00$ & $3.20 \pm 0.73^{\mathrm{a}}$ & $8.60 \pm 0.40^{c}$ & $9.00 \pm 0.32^{\mathrm{c}}$ & $8.60 \pm 1.34$ & $12.20 \pm 1.24^{c}$ & $10.40 \pm 1.52^{c}$ \\
\hline TNA & $1.80 \pm 0.37$ & $7.20 \pm 1.39^{\mathrm{a}}$ & $13.20 \pm 0.49^{c}$ & $17.80 \pm 0.37^{c}$ & $19.40 \pm 1.33^{c}$ & $25.80 \pm 1.93^{c}$ & $26.40 \pm 1.83^{c}$ \\
\hline \multicolumn{8}{|l|}{$\mathrm{CrO}_{3}$} \\
\hline BN & $0.20 \pm 0.20$ & $0.80 \pm 0.37^{\mathrm{a}}$ & $0.40 \pm 0.24$ & $0.20 \pm 0.20$ & $0.60 \pm 0.24$ & $0.40 \pm 0.24$ & $1.00 \pm 0.00$ \\
\hline BUD & $0.00 \pm 0.00$ & $1.40 \pm 0.51$ & $6.00 \pm 0.84^{b}$ & $7.60 \pm 1.03^{c}$ & $14.40 \pm 0.81 \mathrm{c}$ & $18.60 \pm 1.89^{\circ}$ & $17.20 \pm 1.36^{c}$ \\
\hline FRA & $0.40 \pm 0.24$ & $0.80 \pm 0.37$ & $1.40 \pm 0.51$ & $3.00 \pm 0.00^{c}$ & $2.40 \pm 0.24 c$ & $2.80 \pm 0.37^{\circ}$ & $3.60 \pm 0.24^{c}$ \\
\hline NEC & $1.00 \pm 0.00$ & $3.20 \pm 0.73^{\mathrm{a}}$ & $5.20 \pm 0.37^{c}$ & $6.00 \pm 0.32^{c}$ & $6.40 \pm 0.24 c$ & $7.80 \pm 0.73^{c}$ & $18.60 \pm 1.89^{c}$ \\
\hline TNA & $1.80 \pm 0.37$ & $7.20 \pm 1.39^{\mathrm{a}}$ & $13.40 \pm 1.12^{\mathrm{c}}$ & $17.00 \pm 1.30^{c}$ & $25.80 \pm 0.58 c$ & $30.40 \pm 1.12^{\mathrm{c}}$ & $31.80 \pm 1.83^{c}$ \\
\hline \multicolumn{8}{|l|}{$\mathrm{CuO}$} \\
\hline BN & $0.20 \pm 0.20$ & $0.80 \pm 0.37^{\mathrm{a}}$ & $0.60 \pm 0.24$ & $0.20 \pm 0.20$ & $1.00 \pm .032$ & $0.60 \pm 0.24$ & $1.40 \pm 0.37^{\mathrm{a}}$ \\
\hline BUD & $0.00 \pm 0.00$ & $1.40 \pm 0.51$ & $0.60 \pm 0.75^{b}$ & $1.00 \pm 0.55^{\mathrm{a}}$ & $1.20 \pm 0.58^{\mathrm{a}}$ & $3.40 \pm 0.24^{c}$ & $3.20 \pm 0.20^{c}$ \\
\hline FRA & $0.40 \pm 0.24$ & $0.80 \pm 0.37$ & $1.00 \pm 1.00^{c}$ & $1.5 \pm 1.05^{c}$ & $2.00 \pm 1.41^{\circ}$ & $5.40 \pm 0.68^{c}$ & $10.60 \pm 0.98^{c}$ \\
\hline NEC & $1.00 \pm 0.00$ & $3.20 \pm 0.73^{\mathrm{a}}$ & $1.60 \pm 31.9$ & $2.80 \pm 0.58$ & $3.20 \pm 1.24$ & $10.20 \pm 0.68$ & $13.20 \pm 1.02$ \\
\hline TNA & $1.80 \pm 0.37$ & $7.20 \pm 1.39^{\mathrm{a}}$ & $3.80 \pm 31.79^{c}$ & $5.50 \pm 1.55^{c}$ & $7.40 \pm 1.11^{\circ}$ & $18.60 \pm 0.58^{c}$ & $29.40 \pm 1.72^{c}$ \\
\hline \multicolumn{8}{|c|}{ Mixture of As: $\mathrm{Cr}$} \\
\hline $\mathrm{BN}$ & $0.20 \pm 0.20$ & $0.80 \pm 0.37^{a}$ & $0.00 \pm 0.00$ & $0.20 \pm 0.20$ & $0.60 \pm 0.40$ & $0.60 \pm 0.40$ & $1.00 \pm 0.55$ \\
\hline BUD & $0.00 \pm 0.00$ & $1.40 \pm 0.51$ & $3.80 \pm 0.37^{c}$ & $3.00 \pm 0.55^{c}$ & $4.00 \pm 0.32^{c}$ & $6.00 \pm 0.32^{c}$ & $6.80 \pm 0.86^{c}$ \\
\hline FRA & $0.40 \pm 0.24$ & $0.80 \pm 0.37$ & $7.20 \pm 0.49^{c}$ & $6.60 \pm 1.29^{c}$ & $7.80 \pm 1.41^{\circ}$ & $8.60 \pm 1.08^{c}$ & $9.40 \pm 0.24^{c}$ \\
\hline NEC & $1.00 \pm 0.00$ & $3.20 \pm 0.73^{\mathrm{a}}$ & $3.40 \pm 0.40^{b}$ & $3.20 \pm 0.37^{\mathrm{b}}$ & $3.80 \pm 0.20^{c}$ & $6.00 \pm 0.32^{c}$ & $7.60 \pm 0.51^{c}$ \\
\hline TNA & $1.80 \pm 0.37$ & $7.20 \pm 1.39^{\mathrm{a}}$ & $14.40 \pm 0.81^{c}$ & $14.20 \pm 1.77^{c}$ & $16.20 \pm 0.66^{c}$ & $21.20 \pm 1.50^{c}$ & $24.80 \pm 1.74^{c}$ \\
\hline \multicolumn{8}{|c|}{ Mixture of $\mathrm{As:Cu}$} \\
\hline $\mathrm{BN}$ & $0.20 \pm 0.20$ & $0.80 \pm 0.37^{\mathrm{a}}$ & $0.40 \pm 0.40$ & $0.20 \pm 0.20$ & $0.00 \pm 0.00$ & $0.00 \pm 0.00$ & $0.00 \pm 0.00$ \\
\hline BUD & $0.00 \pm 0.00$ & $1.40 \pm 0.51$ & $1.40 \pm 0.40$ & $1.20 \pm 0.58$ & $2.60 \pm 0.75$ & $1.00 \pm 0.45$ & $1.00 \pm 0.45$ \\
\hline FRA & $0.40 \pm 0.24$ & $0.80 \pm 0.37$ & $6.00 \pm 0.71^{c}$ & $6.40 \pm 1.03^{c}$ & $11.80 \pm 0.97^{\circ}$ & $13.80 \pm 0.58^{c}$ & $13.40 \pm 0.40^{c}$ \\
\hline NEC & $0.40 \pm 0.24$ & $3.20 \pm 0.73^{\mathrm{a}}$ & $4.20 \pm 0.73^{\mathrm{a}}$ & $6.40 \pm 1.03$ & $4.80 \pm 1.07^{b}$ & $7.40 \pm 0.51^{c}$ & $8.00 \pm 0.84^{c}$ \\
\hline TNA & $1.80 \pm 0.37$ & $7.20 \pm 1.39^{\mathrm{a}}$ & $12.60 \pm 1.81^{\mathrm{c}}$ & $13.40 \pm 2.34^{c}$ & $19.80 \pm 1.56^{c}$ & $22.20 \pm 1.02^{\mathrm{c}}$ & $22.60 \pm 1.03^{c}$ \\
\hline $\mathrm{Cr}-\mathrm{Cu}$ & Mixture of $\mathrm{Cr}: \mathrm{Cu}$ & & & & & & \\
\hline $\mathrm{BN}$ & $0.20 \pm 0.20$ & $0.80 \pm 0.37^{\mathrm{a}}$ & $0.20 \pm 0.20$ & $0.40 \pm 0.40$ & $0.40 \pm 0.24$ & $1.40 \pm 1.40$ & $0.00 \pm 0.00$ \\
\hline BUD & $0.00 \pm 0.00$ & $1.40 \pm 0.51$ & $0.00 \pm 0.00$ & $0.00 \pm 0.00$ & $0.00 \pm 0.00$ & $0.00 \pm 0.00$ & $0.00 \pm 0.00$ \\
\hline FRA & $0.40 \pm 0.24$ & $0.80 \pm 0.37$ & $4.60 \pm 0.68^{c}$ & $7.00 \pm 0.71^{c}$ & $7.60 \pm 0.75^{c}$ & $7.80 \pm 0.58^{c}$ & $8.60 \pm 0.51^{c}$ \\
\hline NEC & $0.40 \pm 0.24$ & $3.20 \pm 0.73^{\mathrm{a}}$ & $4.00 \pm 0.32^{c}$ & $4.40 \pm 0.40^{c}$ & $6.20 \pm 0.20^{c}$ & $6.00 \pm 0.55^{c}$ & $7.40 \pm 0.40^{c}$ \\
\hline TNA & $1.80 \pm 0.37$ & $7.20 \pm 1.39^{\mathrm{a}}$ & $26.20 \pm 1.77^{c}$ & $18.40 \pm 0.51^{c}$ & $19.40 \pm 1.44^{c}$ & $19.40 \pm 1.44^{c}$ & $19.20 \pm 1.39^{c}$ \\
\hline \multicolumn{8}{|c|}{ Mixture of $\mathrm{As}: \mathrm{Cr}: \mathrm{Cu}$} \\
\hline $\mathrm{BN}$ & $0.20 \pm 0.20$ & $0.80 \pm 0.37^{\mathrm{a}}$ & $0.80 \pm 0.37$ & $1.20 \pm 0.37$ & $1.60 \pm 0.24^{\mathrm{a}}$ & $1.20 \pm 0.37$ & $1.80 \pm 0.37^{\mathrm{a}}$ \\
\hline BUD & $0.00 \pm 0.00$ & $1.40 \pm 0.51$ & $1.20 \pm 0.58^{c}$ & $2.20 \pm 0.58^{c}$ & $4.60 \pm 1.33^{c}$ & $5.40 \pm 0.93^{c}$ & $8.00 \pm 1.05^{c}$ \\
\hline FRA & $0.40 \pm 0.24$ & $0.80 \pm 0.37$ & $3.40 \pm 0.24^{a}$ & $4.80 \pm 1.02^{\mathrm{c}}$ & $6.00 \pm 0.45^{c}$ & $9.40 \pm 0.75^{c}$ & $9.40 \pm 0.81^{c}$ \\
\hline NEC & $1.00 \pm 0.00$ & $3.20 \pm 0.73^{\mathrm{a}}$ & $2.60 \pm 0.40$ & $3.40 \pm 0.81$ & $5.20 \pm 0.80^{c}$ & $7.60 \pm 0.68^{c}$ & $8.80 \pm 0.66^{c}$ \\
\hline TNA & $1.80 \pm 0.37$ & $7.20 \pm 1.39^{\mathrm{a}}$ & $7.08 \pm 0.84^{c}$ & $12.80 \pm 1.39^{c}$ & $17.40 \pm 0.93^{c}$ & $23.60 \pm 1.78^{c}$ & $29.00 \pm 1.52^{c}$ \\
\hline
\end{tabular}

Data are presented as mean \pm standard error. ${ }^{a} p<0.05$; ${ }^{b} p<0.01 ;{ }^{c} p<0.001$ are significantly different from the negative control (borehole tap water) using Dunnett's multiple post hoc comparison test. $\mathrm{BN}=$ Binucleated cells; $\mathrm{BUD}=$ Bud nucleus; $\mathrm{FRA}=$ Fragmented nucleus; $\mathrm{NEC}=$ Necrotic cells; TNA = Total nuclear abnormalities . 
Table 5. Derived interaction factor (IF) for mixtures of $\mathrm{As}: \mathrm{Cr}, \mathrm{As}: \mathrm{Cu}, \mathrm{Cr}: \mathrm{Cu}$ and $\mathrm{As}: \mathrm{Cr}: \mathrm{Cu}$ in the induction of micronucleus (MN) and nuclear abnormalities (NAs) in Clarias gariepinus.

\begin{tabular}{|c|c|c|c|c|c|}
\hline Metal mixture & Conc (\%) & $\mathrm{IF} \pm \mathrm{S} \mathrm{E}_{\mathrm{F}} \mathrm{MN}$ induction & Interaction & $\mathrm{IF} \pm \mathrm{SE} \mathrm{E}_{\mathrm{F}} \mathrm{NAs}$ induction & Interaction \\
\hline \multirow[t]{5}{*}{ As:Cr } & 6.25 & $3.00 \pm 1.15$ & Synergism & $-24.80 \pm 1.51$ & Antagonism \\
\hline & 12.50 & $-2.40 \pm 1.74$ & Antagonism & $-32.80 \pm 2.26$ & Antagonism \\
\hline & 25.00 & $-5.00 \pm 1.48$ & Antagonism & $-42.80 \pm 1.64$ & Antagonism \\
\hline & 50.00 & $-7.80 \pm 2.06$ & Antagonism & $-53.80 \pm 2.71$ & Antagonism \\
\hline & 100.00 & $-13.6 \pm 1.04$ & Antagonism & $-56.30 \pm 3.16$ & Antagonism \\
\hline \multirow[t]{5}{*}{ As:Cu } & 6.25 & $5.60 \pm 1.68$ & Synergism & $-47.20 \pm 31.85$ & Antagonism \\
\hline & 12.50 & $-1.00 \pm 1.43$ & Antagonism & $-22.60 \pm 2.86$ & Antagonism \\
\hline & 25.00 & $-0.80 \pm 1.86$ & Antagonism & $-23.60 \pm 2.36$ & Antagonism \\
\hline & 50.00 & $-3.20 \pm 1.73$ & Antagonism & $-34.00 \pm 2.29$ & Antagonism \\
\hline & 100.00 & $-6.40 \pm 1.52$ & Antagonism & $-37.20 \pm 2.74$ & Antagonism \\
\hline \multirow[t]{5}{*}{$\mathrm{Cr} ; \mathrm{Cu}$} & 6.25 & $-1.00 \pm 1.46$ & Antagonism & $-33.80 \pm 31.86$ & Antagonism \\
\hline & 12.50 & $-5.00 \pm 1.40$ & Antagonism & $-16.80 \pm 2.12$ & Antagonism \\
\hline & 25.00 & $-8.80 \pm 1.09$ & Antagonism & $-30.40 \pm 1.94$ & Antagonism \\
\hline & 50.00 & $-8.60 \pm 1.69$ & Antagonism & $-41.40 \pm 1.95$ & Antagonism \\
\hline & 100.00 & $-10.60 \pm 2.96$ & Antagonism & $-46.00 \pm 2.76$ & Antagonism \\
\hline \multirow[t]{5}{*}{ As:Cr:Cu } & 6.25 & $-3.80 \pm 1.51$ & Antagonism & $-59.20 \pm 31.83$ & Antagonism \\
\hline & 12.50 & $-11.80 \pm 1.48$ & Antagonism & $-35.20 \pm 2.51$ & Antagonism \\
\hline & 25.00 & $-15.00 \pm 1.45$ & Antagonism & $-41.80 \pm 2.08$ & Antagonism \\
\hline & 50.00 & $-18.20 \pm 2.15$ & Antagonism & $-53.00 \pm 2.94$ & Antagonism \\
\hline & 100.00 & $-23.20 \pm 2.09$ & Antagonism & $-53.60 \pm 3.49$ & Antagonism \\
\hline
\end{tabular}

Positive values of $\mathrm{IF}=$ synergism; negative value of $\mathrm{IF}=$ antagonism; $\mathrm{SE}=$ Standard error

fold) $>\mathrm{Cr}: \mathrm{Cu}$ (3.22 fold)>Cu (2.83 fold), compared with the negative control. This indicates that $\mathrm{Cr}$ induced the highest frequency of $\mathrm{MN}$ while $\mathrm{Cu}$ induced the least.

The metals similarly elicited concentration dependent significant ( $p>0.05)$ increase in total nuclear abnormalities (TNAs) in peripheral erythrocytes of treated C. gariepinus (Table 4). The frequently observed NAs; nuclear bud (Bud; Figure $5 b)$, fragmented nucleus (FRA; Figure 5c), necrosis (NEC; Figure 5d) and binucleated erythrocytes (BN; Figure 5e) were scored individually and also as component of TNAs along with others not frequently observed NAs (Figure $5 f-h$ ). These include notch nucleus (Figure 5f), enucleated erythrocyte (Figure 5g), and bleb nucleated erythrocytes (Figure 5h). At 100\% concentrations for individual and mixtures of metals/metalloid, the fold increase in frequencies of NAs was in the order: $\mathrm{Cr}$ (17.67 fold)>Cu (16.33 fold)>As: $\mathrm{Cr}: \mathrm{Cu}$ (16.11 fold) $>$ As (14.67 fold)>As: $\mathrm{Cr}$ (13.78 fold)>As: $\mathrm{Cu}$ (12.56 fold)>Cr:Cu (10.67 fold) when compared with the negative control. Cr induced the highest frequency of NAs, while As: $\mathrm{Cu}$ induced the least numbers of NAs. Surprising observation was higher necrotic and apoptotic erythrocytes that characterized erythrocytes from Cu treated fish (Figure 5k; Table 4).

\section{Analysis of interaction factor}

Analysis of the IF suggests antagonism as the common interactive mechanisms involved between the composite mixture of the tested metal solution in the induction of MN and NAs
(Table 5) except for $6.25 \%$ concentration where As:Cu and As:Cr synergistically interacted to induce MN erythrocytes.

\section{Discussion}

Mixture of metals are commonly encountered in both aquatic and terrestrial environments and this suggests that biological species including humans are simultaneously and or concurrently exposed to myriad of these metals. CCA, a water-soluble wood preservative, has been shown to release $\mathrm{Cr}$, As and $\mathrm{Cu}$ into aquatic environment via multiple routes. This includes leachates generated from landfills containing CCA-treated wood [5,7], As, $\mathrm{Cr}$ and $\mathrm{Cu}$ leaching from CCA coated woods in household and public furniture, wood constructed bridges and enclosures $[4,15,40]$ and most dangerous and direct route is via sub-merging CCA treated logs and timbers into water bodies [11]. This practice was implicated with decline in $C$. gariepinus population inhabiting Lagos Lagoon [23]. However, the mechanism(s) involved in the decline is largely unknown. Herein, acute toxicity and genotoxicity were utilized to unravel possible etiology associated with exposure to individual and mixtures of $\mathrm{As}, \mathrm{Cr}$ and $\mathrm{Cu}$ in aquatic environment using $C$. gariepinus.

Variations in 96-h $\mathrm{LC}_{50}$ of $151.95 \mathrm{mg} / \mathrm{L}$ (Cr) for Mosquito fish (Gambusia affinis) [41], $119.52 \mathrm{mg} / \mathrm{L}$ for Tilapia nilotica, 87.93 mg/L for Cyprinus carpio, $53.57 \mathrm{mg} / \mathrm{L}$ for Ctenopharyngodon idella [42] and indeterminate LC $_{50}$ for Brazilian fish, Piaractus 
mesopotamicus [43] compared to $61.68 \mathrm{mg} / \mathrm{L}$ for C. gariepinus in the study herein showed the influence of model organisms (species, developmental stages and health status) [44] in $\mathrm{LC}_{50}$ determination. Similarly, 96-h $\mathrm{LC}_{50}$ of 28.1 and $15.3 \mathrm{mg} / \mathrm{L}$ $\left(\mathrm{As}_{2} \mathrm{O}_{3}\right)$ for zebrafish and rainbow trout respectively [45], 30.0, 24.5, 10.2 and $22.2 \mathrm{mg} / \mathrm{L}$ for Labeo rohita, Cirrhina mrigala, Catla catla and Ctenopharyngodon idella respectively [46] also showed variation from $213.0 \mathrm{mg} / \mathrm{L}$ As obtained for C. gariepinus in our study. Variations in $\mathrm{LC}_{50}$ values for the same metal in different model organisms suggest that the determination of $\mathrm{LC}_{50}$ for chemicals still remains an important step in preliminary toxicology and environmental risk assessment of chemicals $[44,47]$. That As and $\mathrm{Cu}$ in their binary mixtures with $\mathrm{Cr}$ reduced the mortality response of $C$. gariepinus compared to Cr treatment alone by 2.0 and 1.63 fold respectively, suggests As and $\mathrm{Cu}$ inhibited chromium absorption due to their potential direct interaction at the plasma membrane [48]. This assertion was supported by Isobologram and synergistic (SR) prediction models of antagonistic interactions between $\mathrm{Cr}: \mathrm{Cu}$ and As:Cr. Studies are scarce that assessed joint-action interaction between $\mathrm{Cu}$ and $\mathrm{Cr}$ or As and $\mathrm{Cr}$, however previous report on binary mixture (1:1) of Cu:Zn interaction was via antagonism in eliciting mortality response in juvenile Orechromis niloticus [27]. Similarly, varying the ratio of concentrations (4:1, 3:2 and 1:4) of binary mixture of Cu:Zn interacted antagonistically to elicit mortality response of $T$. fuscatus var radula [28]. Findings from our study suggest antagonistic interaction among individual metals in As: $\mathrm{Cr}: \mathrm{Cu}$ and $\mathrm{As}: \mathrm{Cu}$ in response to increase mortality of $C$. gariepinus. This finding may be useful in the management of CCA polluted sites and setting environmental safe limits for freshwater bodies.

Studies have shown that $\mathrm{Cu}$ has the highest accumulation potential $(\mathrm{Cu}>\mathrm{As}>\mathrm{Cr})$ in sediments and benthos from CCA polluted sites [10,23,25]. For instance, American oysters (Crassostrea virginica; an epibiotic organism) inhabiting CCA contaminated water bio-accumulated as much as $600 \mathrm{ppm} \mathrm{Cu}$ until they turn greenish and were still alive [24]. This report may give support to why all the exposed fish survived even at $600 \mathrm{mg} / \mathrm{L}$ of $\mathrm{Cu}$ treatment. Moreover, all fish exposed to $\mathrm{Cu}$ gained weight compared to the control (Figure 4). An indication that $\mathrm{Cu}$ ion is required for fish physiological needs $[49,50]$. However, the tested concentrations for $\mathrm{Cu}$ (threshold may differ for cells, animals and plants) in this study may become highly toxic eliciting varying systemic toxicity [50-52]. Intriguing was the fact that fish exposed to mixture of As:Cu significantly gained weight compared to the control, unlike fish exposed to As alone (Figure 4) [53]. It may be suggested that $\mathrm{Cu}$ interactively enhance the biotransformation of As into rela- tively harmless substance hence reducing its deleterious effects during the 7 day exposure $[54,55]$. Cr, either when exposed to fish alone or in combination with As and Cu caused reduction in fish body weight gain. Decrease in body weight gain was significant for As:Cr and Cr:Cu compared to the control and $\mathrm{Cr}$ alone (Figure 4). This suggests that the predicted antagonistic interaction between the binary mixtures of the metals apparently caused a reduction in mortality but did not significantly reduce morbidity (changes in physiological and biochemical processes that retarded fish growth were affected) compared to the negative control. This assertion is supported by the clinical signs of toxicity; ulceration, inflammation, oedema of the skin and skin lesion observed in the fish exposed to As, Cr and As:Cr (Figure 3). Furthermore, the observed skin lesions lend credence to the reports that As and $\mathrm{Cr}$ are carcinogens capable of increasing dermatological abnormalities in fish species that may lead to cutaneous and visceral tumor development [56-59]. It further agrees with previous report that long-term human exposure to CCA-treated wood increased cutaneous and visceral malignancy [60]. The derived $\mathrm{SC} ; 6.17 \mathrm{mg} / \mathrm{L}$ (Cr), $21.30 \mathrm{mg} / \mathrm{L}$ (As), $12.28 \mathrm{mg} / \mathrm{L}$ (As:Cr), 10.04 $\mathrm{mg} / \mathrm{L}(\mathrm{Cr}: \mathrm{Cu})$ and $25.46 \mathrm{mg} / \mathrm{L}$ (As: $\mathrm{Cr}: \mathrm{Cu})$ of the metals derived for juvenile $C$. gariepinus in this study are higher than permissible concentrations for aquatic environment from $\mathrm{Ni}$ geria [61] and other International organizations [62,63], suggesting that the test organism may be safe in the natural environment containing these SCs. However, it is pertinent to consider that anthropogenic activities are constantly and increasingly discharging these metals into both the aquatic and terrestrial environments and they readily accumulate in sediments and aquatic forms. For instance, over 100 folds of the predicted SCs herein have been reported in soil samples (As=1292 mg/kg; Cr=1444 mg/kg; and Cu=924 mg/kg) collected from soil surface where CCA treated woods were placed to dry after treatment [64].

Acute toxicity testing provides evidence of overall toxicity of chemicals via mortality, but does not indicate the possible mechanisms leading to the mortality vis-a-vis alterations in pathophysiology, biochemistry and genetic composition of the test models. Moreover, exposure to sub-lethal concentrations of metals may not elicit instant mortality, therefore it is necessary to evaluate the cumulative risk on organism's health using appropriate biomarkers [65]. Cytogenetic biomarkers are useful indicators for monitoring impacts of metals and evaluating the risk of predisposition to genetic related diseases and cancer development [66-69]. Fish MN assay, a sensitive and suitable cytogenetic endpoint, has been in use for over 30 decades for monitoring the impact of chemicals on DNA dam- 
age [70], making MN and NA formation a suitable and acceptable biomarkers of DNA damage induced by clastogens and aneugens [71]. MN and NA formation in erythrocytes of $C$. gariepinus has been confirmed sensitive indices for monitoring structural and numerical chromosomal aberrations induced by individual and mixture of chemical and physical agents both in in situ and in vivo studies [32,33,66,72,73].

The differential fold increase in MN and NA erythrocytes in peripheral blood of $C$. gariepinus exposed to individual and mixture of $\mathrm{As}, \mathrm{Cr}$ and $\mathrm{Cu}$ suggests the varying levels of clastogenic and or aneugenic activities of the metals. The induced MN in exposed C. gariepinus lend credence to the report that Oysters inhabiting a canal with sub-merged CCA-treated woods had two fold higher MN in the gill cells compared to oysters from reference site [25]. Similarly, higher frequency of MN cells were observed in Tradescantia plants cultivated on soil (soil sample analysis; As=1,292 mg/ $/ \mathrm{kg}, \mathrm{Cr}=1,444 \mathrm{mg} / \mathrm{kg}$ and $\mathrm{Cu}=924 \mathrm{mg} / \mathrm{kg}$ ) where CCA-treated woods were laid to dry after treatment [64]. Moreover, the findings herein that individual metals and their mixtures at their respective $96-\mathrm{h} \mathrm{LC}_{50}$ concentrations induced higher fold increase of $\mathrm{MN}$ in fish compared to the positive control (benzene), a known hematogenotoxin [31], is worrisome and suggest management strategies to protect aquatic ecosystems from metal mixture pollution. As and Cr possess the ability to elicit genotoxicity in fish $[74,75]$. Furthermore, environmental and occupational exposure to these metals had been linked to increased genotoxicity and cancer risk [76-78]. Although, $\mathrm{Cu}$ is an essential micronutrient that enhances physiological processes in animals, however it is known to elicit DNA damage when in high concentrations $[51,79,80]$.

Joint-action toxicity among composite mixtures of $\mathrm{As}, \mathrm{Cu}$ and $\mathrm{Cr}$ was evident in the induction of $\mathrm{MN}$ and NAs in C. gariepinus. Synergism was observed in lower concentrations (6.25\%) of As: $\mathrm{Cu}$ and As: $\mathrm{Cr}$ while antagonism was the most common interaction among the CCA constituents (Table 5). Previous studies have shown that DNA and protein damage may involve both forms of interactions. For instance, both interactions were observed between lead tetra-acetate and $\mathrm{As}_{2} \mathrm{O}_{3}$ in the induction of $\mathrm{MN}$ in Tradescantia plant [81]. Synergism between $\mathrm{Cu}$ and $\mathrm{Zn}$ caused higher $\mathrm{MN}$ formation in peripheral erythrocyte of exposed Tilapia species compared to individual $\mathrm{Cu}$ and $\mathrm{Zn}$ [79]. Also, antagonism between $\mathrm{Cu}$ and Zn caused decrease in DNA, RNA and protein damage in fathead minnows, Pimephales promelas than individual $\mathrm{Cu}$ and $\mathrm{Zn}$ [82]. These interactions depend largely on the toxicokinetics of the metals, which to a greater extent determine changes in the processes involving absorption, distribution, metabo- lism, and or excretory effects of one metal on the others [83]. The interactive effects of metal mixtures may also depend on the sensitivity of the selected biomarkers of toxicity and the model organisms [84]. The findings herein may suggest that As synergistically interacted with $\mathrm{Cu}$ in the exposed fish to enhanced $\mathrm{Cu}$ accumulation in the kidney (hematopoietic system of the fish) which led to higher MN and NAs formation via oxidative stress compared to the individual $\mathrm{As}$ and $\mathrm{Cu}$. This assertion lends credence to the report of Ademuyiwa et al.[85] wherein they observed that $\mathrm{As}_{2} \mathrm{O}_{3}$ increased $\mathrm{Cu}$ accumulation in kidney of exposed rats relative to the control group. Furthermore, antagonistic interaction observed herein suggests increase metallothionein production, hence it leads to metal sequestration and decrease free radical formation (ameliorating metal toxicity) [86-88]. This is supported by the report that coexposure between $\mathrm{Pb}$ or $\mathrm{Cd}$ significantly reduced As accumulation in the kidney of rats, leading to the suppression of oxidative stress [89].

NAs in C. gariepinus along with $\mathrm{MN}$ has been shown to be sensitive, reliable and suitable as biomarker of cytogenotoxicity elicited by mixtures of xenobiotics and it suggests possible mechanisms of genome instability in fish [32-34,66,90]. For instance, the presence of nuclear bud has been linked with entrapment of amplified DNA and/or DNA repair complexes during S-phase [91]. While binucleated cell formation results from alterations during cytokinesis of the $\mathrm{M}$ phase of dividing cells not previously exposed to cytochalasin-B [92]. Fragmented apoptotic bodies with membrane-bound cells, and cells with loss of membrane integrity (Necrosis) (Figure 5c-d,i-k) suggest that the binary and tri-metal mixtures of CCA constituents caused damage to the hematopoietic system of the exposed fish, and the damage cells were eliminated by either programmed cell death (apoptosis) or accidental cell death (necrosis) [93]. It is also possible that CCA metals induced p53 protein expression which caused activation of antioxidant genes associated with apoptotic cell formation [94]. $\mathrm{Cr}$, $\mathrm{Cu}$ and As are capable of generating excess cellular levels of reactive oxygen species which are capable of causing damage to p53 proteins and or genes associated with p53 expression. This can lead to activation of cell death processes; necrosis and apoptosis, via inactivation of antioxidant species [96]. This assertion aligns with the reports that $\mathrm{Cr}$, $\mathrm{Cu}$ and As have the ability to interfere with cellular activity through different mechanisms which may lead to cell lysis, cellular inflammation and/or cell death [95]. Necrotic and apoptotic erythrocytes had been previously observed in juvenile $C$. gariepinus exposed to hospital effluent [33]. 


\section{Conclusion}

In conclusion, joint-action acute toxicity and cytogenotoxic effects of As, $\mathrm{Cr}$ and $\mathrm{Cu}$ binary and tri-metal composite mixtures showed departure from the actions of individual metals in C. gariepinus. The 96-h acute toxicity showed that $\mathrm{Cr}$ was the most toxic metal while $\mathrm{Cu}$ and $\mathrm{As}: \mathrm{Cu}$ were indeterminate. According to Isobologram and SR models, As: $\mathrm{Cr}$ and $\mathrm{Cr}: \mathrm{Cu}$ interacted antagonistically while As: $\mathrm{Cu}$ interacted synergistically. Furthermore, concentration-addition model showed synergism for As:Cr:Cu, while the IF deduced that high concentrations of individual metals in the composite mixtures interacted antagonistically to elicit MN and NAs in erythrocytes of exposed fish. The findings herein may suggest possible in situ interactive effects among $\mathrm{Cr}, \mathrm{Cu}$ and As in contaminated aquatic environment in the elicitation of acute toxicity and cytogenotoxicity in aquatic forms. Increase in genomic instability may predispose fish and other aquatic organisms to genetic related diseases including cancer. The derived SCs of individual and mixture of $\mathrm{Cr}$, $\mathrm{Cu}$ and As may be relevant in establishing environmental relevant concentrations / safe limits for the component metals in CCA.

\section{Conflict of interest}

The authors declare that no form of conflict of interest exists.

\section{References}

1. Tosam MJ, Mbih RA. Climate change, health, and sustainable development in Africa. Environ Develop Sustaina 2015;17(4):787-800.

2. Beckett WS, Nordberg GF, Clarkson TW. Routes of exposure, dose and metabolism of metals. In: G.F. Nordberg, B.A. Fowler, M. Nordberg, L. Friberg, editors, Handbook on the toxicology of metals. 3rd ed. Academic Press, Inc; 2005, p. 39-64.

3. Gress J, de Oliveira LM, da Silva EB, Lessl JM, Wilson PC, Townsend T et al., Cleaning-induced arsenic mobilization and chromium oxidation from CCA-wood deck: Potential risk to children. Environ Int 2015;82:35-40.

4. Gress J, da Silva EB, de Oliveira LM, Zhao D, Anderson G, Heard D et al., Potential arsenic exposures in 25 species of zoo animals living in CCA-wood enclosures. Sci Total Environ 2016;551-552:614-621.

5. Karnchanawong S, Veerakajohnsak C. Arsenic, chromium, and copper leaching from CCA-treated wood and their potential impacts on landfill leachate in a tropical country. Environ Technol 2010;31(4): 381-394.

6. Mercera TG, Frostick LE. Evaluating the potential for environmental pollution from chromated copper arsenate (CCA) treated wood waste: A new mass balance approach. J Hazard Mater 2014;276:10-18.

7. Saxe JK, Wannamaker EJ, Conklin SW, Shupe TF, Beck BD. Evaluating landfill disposal of chromated copper arsenate (CCA) treated wood and potential effects on groundwater: Evidence from Florida. Chemosphere 2007;66(3):496-504.

8. Takahashi N, Yoshida T, Kojima S, Yamaguchi S, Ohtsuka R, Takeda M et al., Pathological and clinical pathological changes induced by fourweek, repeated-dose, oral administration of the wood preservative chromated copper arsenate in Wistar rats. Toxicol Pathol 2018;46(3): 312-323.

9. Lyytikäinen M. Transport, bioavailability and effects of Ky-5 and CCA wood preservative components in aquatic environment. [dissertation] University of Joensuu. Finland; 2004, p.102.

10. Weis JS, Weis P. The effects of using wood treated with chromated copper arsenate in shallow-water environments. A Review. Estuaries 1996;19(2):306-310.

11. Hingston JA, Collins CD, Murphy RJ, Lester JN. Leaching of chromated copper arsenate wood preservatives: A review. Environ Pollut 2001;111(1):53-66.

12. Hu L, Diez-Rivas C, Hasan AR, Solo-Gabriele H, Fieber L, Cai Y. Transport and interaction of arsenic, chromium, and copper associated with CCA-treated wood in columns of sand and sand amended with peat. Chemosphere 2010;78(8):989-995.

13. Janin A, Zaviska F, Drogui P, Blais J, Mercier G. Selective recovery of metals in leachate from chromated copper arsenate treated wastes using electrochemical technology and chemical precipitation. Hydrometallurgy 2009;96(4):318-326.

14. Ko BG, Vogeler I, Bolan NS, Clothier B, Green S, Kennedy J. Mobility of copper, chromium and arsenic from treated timber into grapevines. Sci Total Environ 2007; 388(1-3):35-42.

15. McQueen J, Stevens J. Disposal of CCA-treated wood. Forest Products J 1998;48(11/12): 86-90.

16. Bhattacharjee P, Banerjee M, Giri AK. Role of genomic instability in arsenic-induced carcinogenicity. A review. Environ Int 2013;53:29-40.

17. Nigam A, Priya S, Bajpai P, Kumar S. Cytogenomics of hexavalent chromium (Cr6+) exposed cells: a comprehensive review. Indian J Med Res 2014;139(3):349-370.

18. Ohgami N, Yamanoshita O, Thang ND, Yajima I, Nakano C, Wenting W et al., Carcinogenic risk of chromium, copper and arsenic in CCAtreated wood. Environ Pollut 2015;206:456-460.

19. United State Environmental Protection Agency. Response to requests to cancel certain chromated copper crsenate (CCA) wood preservative products and amendments to terminate certain uses of other CCA Products, FRL-7301-2. Washington, DC: US Environmental Protection Agency. 2003.

20. Jambeck J, Weitz K, Solo-Gabriele H, Townsend T, Thorneloe S. CCATreated wood disposed in landfills and life-cycle trade-offs with waste-to-energy and MSW landfill disposal. Waste Manage 2007; 27(8):S21-S28.

21. Merkle PB, Gallagher D, Solberg TN. Leaching rates, metals distribution, and chemistry of CCA treated lumber: implications for water quality modeling. In: Environmental considerations in the manufacture, use and disposal of preservative-treated wood. Madison, WI: Forest Products Society; 1993, p. 69-78.

22. Sogbanmu TO, Fatunsin OT, Echebiri FO, Otitoloju AA, Olayinka KO. Fish decline in the Lagos Lagoon, Nigeria: impacts of Saw-Milling activities on Clarias gariepinus (African mud catfish) embryos. Poster presented at 2017 Common Wealth Science conference; 2017 Jun 13- 
16; Singapore.

23. Weis JS, Weis P. Effects of contaminants from chromated copper arsenate-treated lumber on benthos. Arch Environ Contam Toxicol 1994;26(1):103-109.

24. Schuster CN. Pringle BH. Trace metal accumulation by the American oyster, Crassostrea virginica. Proceedings of the National Shellfisheries Association. 1969;59:91-103.

25. Weis P, Weis JS, Couch J, Daniels C, Chend T. Pathological and genotoxicological observations in Oysters (Crassostrea virginica) living on chromated copper arsenate (CCA)-treated wood. Marine Environ Res 1995;39(1-4):275-278.

26. Klutse CK, Mack K, Squibb K, Ishaque AB. Differential toxicological interaction among arsenic, cadmium, lead and mercury on MCF7 cell line. Scholar. Res. Exchange 2009,789636;1-5.

27. Obiakor MO, Ezeonyejiaku CD. Copper-zinc co-ergisms and metal toxicity at predefined ratio concentrations: Predictions based on synergistic ratio model. Ecotoxicol Environ Safe 2015;117:149-154.

28. Otitoloju AA. Evaluation of the joint-action toxicity of binary mixtures of heavy metals against the mangrove periwinkle Tympanotonus fuscatus varradula (L.). Ecotoxicol Environ Safe 2002; 53(3):404-415.

29. Organization for Economic Co-operation and Development . Guideline 210 for testing of chemical. Fish, early-life stage toxicity testing. Adopted by the council on 17th July, 1992. p. 1-18.

30. European Inland Fisheries Advisory Commission. Revised report on fish toxicology testing procedures. Rome: Food and Agriculture Organization of the United Nations, 1998. (EIFAC technical paper, No. 24).

31. WHO. Benzene in drinking-water. Background document for development of WHO guidelines for drinking-water quality. Geneva, World Health Organization 2003.

32. Alimba CG, Bakare AA. In vivo micronucleus test in the assessment of cytogenotoxicity of landfill leachates in three animal models from various ecological habitats. Ecotoxicol 2016;25(2):310-319.

33. Alimba CG, Ajiboye RD, Fagbenro OS. Dietary ascorbic acid reduced micronucleus and nuclear abnormalities in Clarias gariepinus (Burchell 1822) exposed to hospital effluent. Fish Physiol Biochem 2017;43(5):1323-1335.

34. Alimba CG, Adekoya KO, Soyinka OO. Exposure to effluent from pharmaceutical industry induced cytogenotoxicity, hematological and histopathological alterations in Clarias gariepinus (Burchell, 1822). EXCLI J 2019;18:63-78.

35. Christensen ER Chen CY. A General non-interactive multiple toxicity model including probit, logit, and weibull transformations. Biometrics 1985;41(3):711-725.

36. Thorpe KL, Gross-Sorokin M, Johnson I, Brighty G, Tyler CR. An assessment of the model of concentration addition for predicting the estrogenic activity of chemical mixtures in wastewater treatment works effluents. Environ Health Perspect 2006;114(Suppl 1):90-97.

37. Tallarida RJ. An overview of drug combination analysis with Isobolograms. J Pharmacol Exp Ther 2006;319(1):1-7.

38. Katsifis SP, Kinney PL, Hosselet S, Bums FJ, Christie NT. Interaction of nickel with mutagens in the induction of sister chromatid exchanges in human lymphocytes. Mutat Res 1996;359(1):7-15.

39. Danesi CC, Dihl RR, Bellagamba BC, de Andradec HHR, Cunha KS, Guimarães NN, et al. Genotoxicity testing of combined treatment with cisplatin, bleomycin, and 5-fluorouracil in somatic cells of Dro- sophila melanogaster. Mutat Res 2012;747(2):228-233.

40. Leduc F, Whalen JK, Sunahara GI. Growth and reproduction of the earthworm Eisenia fetida after exposure to leachate from wood preservatives. Ecotoxicol Environ Saf 2008;69(2):219-226.

41. Begum G, Rao JV, Srikanth K. Oxidative stress and changes in locomotor behavior and gill morphology of Gambusia affinis exposed to chromium. Toxicol Environ Chem 2006;88(2):355-365.

42. Shaukat T, Javed M. Acute toxicity of chromium for Ctenopharyngodon idella, Cyprinus carpio and Tilapia nilotica. Int J Agric Biol 2013; 15(3):590-594.

43. Castro MP, de Moraes FR, Fujimoto RY, da Cruz C, de Andrade Belo MA, de Moraes JRE. Acute toxicity by water containing hexavalent or trivalent chromium in native Brazilian fish, Piaractus mesopotamicus: anatomopathological alterations and mortality. Bull Environ Contam Toxicol 2014;92:213-219.

44. Wong CK, Pak AP. Acute and subchronic toxicity of the heavy metals copper, chromium, nickel, and zinc, individually and in mixture, to the freshwater Copepod Mesocyclops pehpeiensis. Bull Environ Contam Toxicol 2004;73(1):190-196.

45. Tisler T, Zagorc-Koncan J. Acute and chronic toxicity of arsenic to some aquatic organisms. Bull Environ Contam Toxicol 2002;69(3): 421-429.

46. Kousar S, Javed M. Heavy metals toxicity and bioaccumulation patterns in the body organs of four fresh water fish species. Pak Vet J 2014;34(2):161-164.

47. United States Environmental Protection Agency. Aquatic toxicity information, 2005. Retrieve AQUIRE aquatic toxicology database [cited 20YY MMM DD]. Available from: www.epa.gov/ecotox/accesse

48. Gomes MA, Hauser-Davis RA, Suzuki MS, Vitória AP. Plant chromium uptake and transport, physiological effects and recent advances in molecular investigations. Ecotoxicol Environ Saf 2017;140:55-64.

49. Kamunde CN, Wood CM. Environmental chemistry, physiological homeostasis, toxicology, and environmental regulation of copper, an essential element in freshwater fish. Aus J Ecotoxicol 2004;10:1-20.

50. Lundebye AK, Berntssen MHG, Wendelaar Bonga SE, Maage A. Biochemical and physiological responses in Atlantic Salmon (Salmosalar) following dietary exposure to copper and cadmium. Marine Pollut Bull 1999;39(1-12):137-144.

51. Alimba CG, Dhillon V, Bakare AA, Fenech M. Genotoxicity and cytotoxicity of chromium, copper, manganese and lead, and their mixture in WIL2-NS human B lymphoblastoid cells is enhanced by folate depletion. Mutat Res Genet Toxicol Environ Mutagen 2016;798-799:3547.

52. Wilson RW, Taylor EW. The physiological responses of freshwater rainbow trout, Oncorhynchus mykiss, during acutely lethal copper exposure. J Comp Physiol B 1993;163(1):38-47.

53. Erickson RJ, Mount DR, Highland TL, Hockett JR, Leonard EN, Mattson VR, et al. Effects of copper, cadmium, lead, and arsenic in a live diet on juvenile fish growth. Can J Fisher Aqua Sci 2010;67(11):18161826 .

54. Zhang W, Chen L, Zhou Y, Wu Y, Zhang L. Biotransformation of inorganic arsenic in a marine herbivorous fish Siganus fuscescens after diet borne exposure. Chemosphere 2016;147:297-304.

55. Zhang W, Wang WX, Zhang L. Comparison of bioavailability and biotransformation of inorganic and organic arsenic to two marine fish. 
Environ Sci Technol 2016;50(5):2413-2423.

56. Goldbohm RA, Tielemans EL, Heederik D, Rubingh CM, Dekkers S, Willems MI, et al. Risk estimation for carcinogens based on epidemiological data: A structured approach, illustrated by an example on chromium. Regul Toxicol Pharmacol 2006;44(3):294-310.

57. Rossman, TG. Mechanism of arsenic carcinogenesis: an integrated approach. Mutat. Res. 2003; 533(1-2):37-65.

58. Salnikow K, Zhitkovic A. Genetic and epigenetic mechanisms in metal carcinogenesis and cocarcinogenesis: nickel, arsenic, and chromium. Chem Res Toxicol 2008;21(1):28-44.

59. Shi H, Shi X, Liu KJ. Oxidative mechanism of arsenic toxicity and carcinogenesis. Mol Cell Biochem 2004;255(1-2):67-78.

60. Chen AY, Olsen T. Chromated copper arsenate-treated wood: a potential source of arsenic exposure and toxicity in dermatology. Int J Womens Dermatol 2016;2(1);28-30.

61. National Environmental Standards and Regulations Enforcement Agency. National environ-mental (surface and groundwater quality) regulations. Abuja, Nigeria: NESREA, 2011.

62. United States Environmental Protection Agency. The 2013 annual effluent guidelines review report. 2014. [cited 2019 May 14]. Available from: http://www.epa.gove/sites/production/files/2015-06/ documents/2013-annual-effluent-guideline-review-report.pdf.

63. World Health Organization. Guideline for drinking water quality. 4th ed., NLM classification: WA 675, World Health Organization, Geneva, Switzerland; 2011, p307-433

64. Sandhu SS, Gill BS, Rice JW. Application of Tradescantia micronucleus assay for in situ evaluation of potential genetic hazards from exposure to chemicals at a wood-preserving site. Hazard Waste Hazard Mater 1991;8(3):257-261.

65. Ryan PB, Burke TA, Cohen Hubal EA, Cura JJ, McKone TE. Using biomarkers to inform cumulative risk assessment. Environ Health Perspect 2007;115(5):833-840.

66. Alimba CG, Saliu JK, Ubani-Rex OA. Cytogenotoxicity and histopathological assessment of Lekki Lagoon and Ogun River in Synodontis clarias (Linnaeus, 1758). Toxicol Environ Chem 2015;97(2):221-234.

67. Hussain B, Sultana T, Sultana S, Mahboob S, Al-Ghanim KA, Nadeem S. Variation in genotoxic susceptibility and biomarker responses in Cirrhinus mrigala and Catla catla from different ecological niches of the Chenab River. Environ Sci Pollut Res Int 2016;23(14):14589-14599.

68. Russo A, Degrassi F. Molecular cytogenetics of the micronucleus: still surprising. Mutat Res 2018;836:36-40.

69. Teles M, Pacheco M, Santos MA. Physiological and genetic responses of European eel (Anguilla anguilla L.) to short term chromium or copper exposure influence of pre-exposure to a PAH-like compound. Environ Toxicol 2005;20(1):92-99.

70. Gutiérrez JM, Villar S, Plavan AA. Micronucleus test in fishes as indicators of environmental quality in sub-estuaries of the Río de la Plata (Uruguay). Marine Pollut Bull 2015;91(2):518-523.

71. Udroiu I. The micronucleus test in piscine erythrocytes. Aquat Toxicol 2006;79(2):201-204.

72. Bahari IB, Noor FM, Daud NM. Micronucleated erythrocytes as an assay to assess actions by physical and chemical genotoxic agents in Clarias gariepinus. Mutat Res 1994;313(1):1-5.

73. Harabawy AS, Ibrahim AT. Sub-lethal toxicity of carbonfuran pesticide on the African catfish Clarias gariepinus (Burchell, 1822): Heamato- logical, biochemical and cytogenetical response. Ecotoxicol Environ Saf 2014;103:61-67.

74. Bakshi A, Panigrahi AK. A comprehensive review on chromium induced alterations in fresh water fishes. Toxicol Rep 2018;5:440-447.

75. Minatel BC, Sage AP, Anderson C, Hubaux R, Marshall EA, Lam WL, et al. Environmental arsenic exposure: From genetic susceptibility to pathogenesis. Environ Int 2018; 112:183-197.

76. Kitchin KT. Recent advances in arsenic carcinogenesis: modes of action, animal model systems, and methylated arsenic metabolites. Toxicol Appl Pharmacol 2001;172(3):249-261.

77. Leonard A, Lauwerys RR. Carcinogenicity, teratogenicity and mutagenicity of arsenic. Mutat Res 1980;75(1):49-62.

78. Vaglenov A, Nosko M, Georgieva R, Carbonell E, Creus A, Marcos R. Genotoxicity and radioresistance in electroplating workers exposed to chromium. Mutat Res 1999; 446(1):23-34.

79. Bagdonas E, Vosylienè MZ. A study of toxicity and genotoxicity of copper, zinc and their mixture to rainbow trout (Oncorhynchus mykiss). Biologija 2006;1:8-13.

80. Kumar A, Kesari VP, Khan PK. Fish micronucleus assay to assess genotoxic potential of arsenic at its guideline exposure in aquatic environment. Biometals 2013;26(2):337-346.

81. Ma TH, Sandhu SS, Peng Y, Chen TD, Kim TW. Synergistic and antagonistic effects on genotoxicity of chemicals commonly found in hazardous waste sites. Mutat Res 1992;270(1):71-77.

82. Parrott JL, Sprague JB. Pattern in toxicity of sub-lethal mixtures of metals and organic chemicals determined by microtox and by DNA, RNA, and protein content of Fathead minnows (Pimephales promelas). Can J Fisher Aquat Sci 1993;50(10):2245-2253.

83. Jadhav SH, Sarkar SN, Ram GC, Tripathi HC. Immunosuppressive effect of subchronic exposure to a mixture of eight heavy metals, found as groundwater contaminants in different areas of India, through drinking water in male rats. Arch Environ Contam Toxicol 2007;53(3): 450-458.

84. Wang G, Fowler BA. Roles of biomarkers in evaluating interactions among mixtures of lead, cadmium and arsenic. Toxicol Appl Pharmacol 2008;233(1):92-99.

85. Ademuyiwa O, Elsenhans B, Nguyen PT, Forth N. Arsenic-copper interaction in the kidney of the rat: influence of arsenic metabolites. Pharmacol Toxicol 1996;78(3):154-160.

86. Doering JA, Beitel SC, Eisner BK, Heide T, Hollert H, Giesy JP, et al. Identification and response to metals of metallothionein in two ancient fishes: White sturgeon (Acipenser transmontanus) and lake sturgeon (Acipenser fulvescens). Comp Biochem PhysiolC Toxicol Pharmacol2015;171:41-48.

87. Falnoga I, Stibilj V, Tusek-Znidaric M, Slejkovec Z, Mazej D, Jacimovic $\mathrm{R}$, et al. Effect of arsenic trioxide on metallothionein and its conversion to different arsenic metabolites in hen liver. Biol Trace Elem Res 2000;78(1-3):241-254.

88. Kumar D, Malik DS, Gupta V. Fish metallothionien gene expression: a good bio-indicator for assessment of heavy metal pollution in aquatic ecosystem. Int Res J Environ Sci 2017;6(7):58-62.

89. Wang G. Interactive effects of chronic co-exposure to lead, cadmium or arsenic at LOEL dose levels: Alterations in molecular biomarkers of oxidative damage and expression of cellular protective factors in rat kidneys. [Dissertation]. University of Maryland Baltimore. 2005. 
90. Carrasco KR, Tilbury KL, Myers MS. Assessment of the piscine micronucleus test as an in situ bio-indicator of chemical contaminant effects. Can J Fisher Aqua Sci 1990;47(11):2123-2136.

91. Shimizu N, Itoh N, Utiyama H, Wahl GM. Selective entrapment of extra-chromosomally amplified DNA by nuclear budding and micronucleation during S phase. J Cell Biol 1998;140(6):1307-1320.

92. Fenech M, Kirsch-Volders M, Natarajan AT, Surralles J, Crott JW, Parry J, et al. Molecular mechanisms of micronucleus, nucleoplasmic bridge and nuclear bud formation in mammalian and human cells. Mutagenesis 2011;26(1):125-132.

93. Jimi S, Uchiyama M, Takaki A, Suzumiya J, Hara S. Mechanisms of cell death induced by cadmium and arsenic. Ann N Y Acad Sci 2004;1011: 325-331.

94. Ye J, Wang S, Leonard SS, Sun Y, Butterworth L, Antonini J, et al. Role of reactive oxygen species and p53 in chromium(VI)-induced apoptosis. J Biol Chem 1999; 274(49):34974-34980.

95. Leonard SS, Bower JJ, Shi X. Metal-induced toxicity, carcinogenesis, mechanisms and cellular responses. Mol Cell Biochem 2004;255(12):3-10.

96. Redza-Dutordoir M, Averill-Bates DA. Activation of apoptosis signalling pathways by reactive oxygen species. Biochim Biophys Acta 2016;1863(12):2977-2992. 